\title{
Analysis of factors influencing the growth of the Hungarian top 5000
}

\section{Etelka Katits, Éva Szalka}

Széchenyi István University, Kautz Gyula Faculty of Economics, Egyetem tér 1. 9026 Győr, Hungary

Email address:

katitse@sze.hu (E. Katits), szeva@sze.hu (É. Szalka)

To cite this article:

Etelka Katits, Éva Szalka. Analysis of Factors Influencing the Growth of the Hungarian Top 5000. Science Journal of Business and Management. Special Issue: Business Analytics and Management. Vol. 3, No. 1-2, 2015, pp. 10-25. doi: 10.11648/j.sjbm.s.2015030102.12

\begin{abstract}
After the system change period, many Hungarian macro- and micro-level analyzes were published, but what we lack is a work in evaluating the performance of the corporate sector, which includes the greatest companies. We present the results of empirical data analysis in 5000 the greatest Hungarian corporate sector. All these can contribute to the work of financial management.
\end{abstract}

Keywords: Growth Rate, ROA, ROE, Profitability, Assets Turnover, Equity Multiplier

\section{Introduction}

In this work we examine the growth potential of the Hungarian enterprises ranging from the five branches of the economy between 1992-2012 highlight the strengths and weaknesses of the sector management. We discuss the analysis of the combined company's business activities financing of the exploration well - primarily through internal and external means.
Table 1. The ownership enterprise size categories

\begin{tabular}{lll}
\hline Categories & $\begin{array}{l}\text { The ratio of the foreign ownership } \\
\text { and of the subscribed capital }\end{array}$ & $\begin{array}{l}\text { Ratio in the } \\
\text { database (\%) }\end{array}$ \\
\hline $\begin{array}{l}\text { DOMESTIC } \\
\text { company }\end{array}$ & Less than $50 \%$ & 61,8 \\
$\begin{array}{l}\text { FOREIGN } \\
\text { company }\end{array}$ & Greater than $50 \%$ & 38,2 \\
\hline
\end{tabular}

Source: Own construction and calculation CSO (1992-2012) database

Table 2. Number of firms national economic sectors and the majority ownership broken down by

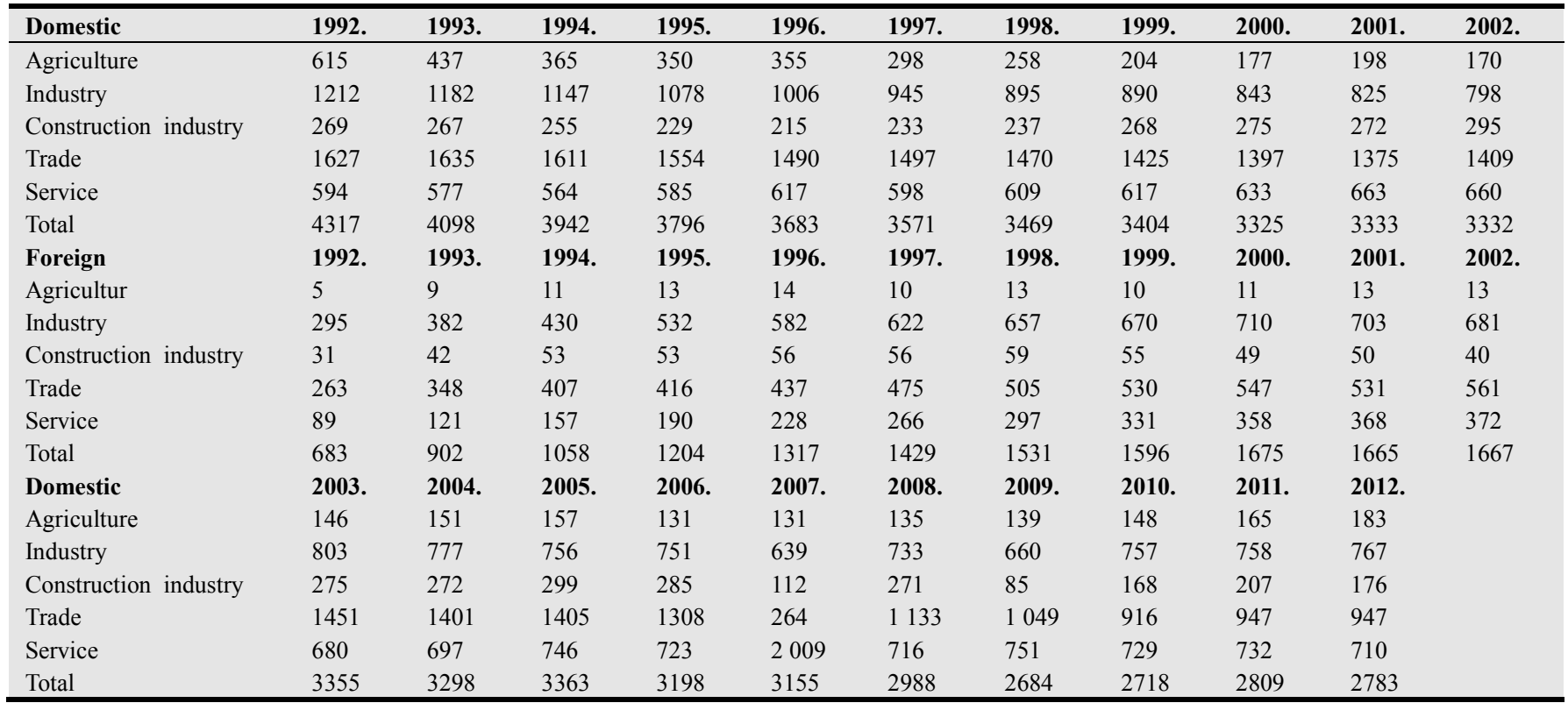




\begin{tabular}{lllllllllll}
\hline Foreign & $\mathbf{2 0 0 3}$ & $\mathbf{2 0 0 4}$ & $\mathbf{2 0 0 5}$ & $\mathbf{2 0 0 6 .}$ & $\mathbf{2 0 0 7}$ & $\mathbf{2 0 0 8}$. & $\mathbf{2 0 0 9}$ & $\mathbf{2 0 1 0 .}$ & $\mathbf{2 0 1 1 .}$ & $\mathbf{2 0 1 2 .}$ \\
Agricultur & 8 & 8 & 10 & 6 & 7 & 7 & 13 & 12 & 10 & 19 \\
Industry & 683 & 696 & 652 & 703 & 674 & 628 & 690 & 735 & 751 & 766 \\
Construction industry & 37 & 44 & 42 & 49 & 27 & 63 & 70 & 49 & 51 & 45 \\
Trade & 549 & 562 & 538 & 595 & 55 & 601 & 518 & 508 & 521 & 517 \\
Service & 367 & 391 & 395 & 449 & 1081 & 506 & 556 & 562 & 524 & 541 \\
Total & 1644 & 1701 & 1637 & 1802 & 1844 & 1805 & 1847 & 1866 & 1857 & 1888 \\
\hline
\end{tabular}

Source: Own construction and calculation CSO (1992-2012) database

\begin{tabular}{|c|c|c|}
\hline 1. Profitability situation & 2. Financial situation & \\
\hline Profitability rates & $\mathbf{D}_{\text {Likvidity rates }}$ & \\
\hline Profit and cash based & Indebtedness rates and rates of the creditworthiness & 2 \\
\hline break-even point analysis & $\mathbf{D}_{\text {Efficiency rates }}$ & 3. Property situation \\
\hline Degree of Operating, & Growth rates & \\
\hline Financial and Combined & Financing force & \\
\hline \multirow[t]{4}{*}{ Leverage } & Capital market based evaluation rates & \\
\hline & Fund flow statement & \\
\hline & Cash flow calculations & \\
\hline & EBIT-EPS analysis & \\
\hline
\end{tabular}

Source: modified by [5] and [14].

Figure 1. The proposal for the analysis of financial performance

FINANCE AND ECONOMIC PERFORMANCE = GROWTH CHANCE ?!
What is the trends in sales revenue and profitability? - Operating, net and clean profitability.
What is the changes in liquidity? - The size and composition of the working capital. The static liquidity.
"We have managed profitably while paying capable stayed ?!"
How stable is the financing?-Ownership and debt ratio
What kind financing of the investments? - The profitability, efficiency requirements realization.
What are the growth potentials? - The internal, sustainable and self-financeable growth rates. Value drivers.
The strong and weak signals, well as the reasons of the crisis (1992-2012).
The proposal: turnaround with value-driven management.

Figure 2. The logic of the analysis Source: Own construction

Examine the business management of the balance sheet and income statement data used, from a single database ${ }^{1}$. This database contains the 1992-2012 period the main lines of the annual income statement and of the closing balance sheet. Because the database is made Excel spreadsheet, so the calculations were carried out in it. The dataset was analyzed on the basis of the following three criteria grouping. The dataset is grouped according to rate of foreign ownership (Table 1).

1 The Central Statistical Office (CSO), the period between 1992-2012, the Hungarian company TOP 5000 sample.
The data in Table 1, on average, 61.8 percent of the firms examined Hungarian majority owned. The table and the figures reported DOMESTIC means that the majority of the domestic company or a $100 \%$ Hungarian ownership. In the case of FOREIGN enterprises in the hungarian minority shareholders are, or do not participate in the decision-making.

Table 2 shows the number of firms within five national economy branch, according to the majority ownership in 20 years.

Categorization of the size of the number of categories used in the European Union (Table 3). 
Table 3. The enterprises size categories

\begin{tabular}{llccc}
\hline \multirow{2}{*}{ Categories } & \multirow{2}{*}{ Manpower } & \multicolumn{3}{c}{ Ratio in the database (\%) } \\
\cline { 3 - 5 } & & DOMESTIC & FOREIGN & All \\
\hline Microenterprises & $1-9$ & 31,5 & 27,8 & 30,3 \\
Small business & $10-49$ & 38,4 & 37,2 & 38,0 \\
Medium business & $50-249$ & 13,2 & 14,4 & 13,6 \\
Big enterprise & Over 250 & 16,9 & 20,6 & 18,1 \\
\hline
\end{tabular}

Source: Own construction and calculation on the database of CSO (19922012)

So more than $3 / 4$ of the studied corporate sector of small and medium enterprises represent. More than 10 percent of those represented in the business, which provides the main activities of 50 or more staff.

National economic sectors according to the categorization shown in Table 4.

Table 4. The average rate of national economic sectors

\begin{tabular}{ll}
\hline Categories & Ratio in the database (\%) \\
\hline A: Agriculture & 3,2 \\
B, C, D, E: Industry & 28,6 \\
F: Construction industy & 4,4 \\
G: Trade & 26,6 \\
H-P: Service & 37,2 \\
\hline
\end{tabular}

Source: Own construction and calculation on the database of CSO (19922012)

Only some items from the balance sheet and income statement were analyzed, so all financial method presented in Figure 1, we could not apply, only the blue candidates.

After the presentation of the database and the analytical instruments used are given the logic of the analysis, as shown in Figure 3.

In the next part we present our in Figure 2 presented analysis the logic according and in Figure 1 in blue indicate the financial calculations results. After that, we have been given in our say, as if we were a financial analyst.

\section{The Prospects for Growth versus Growth Chances}

The growth prospects of the national economic sectors we examine in three ways:

1. Internal growth rate (IGR): the relevant branch of the national economy without use of external sources, that is self-financing below. So the only sources of financing are from the retained profits $[2,8,10]$.

2. Sustainable growth rate (SGR): the branches of the economy have examined capital structure remains unchanged, the company did not issue - publicly - the additional shares. So it is a growth that without the involvement of the additional equity, or remain unchanged in the long-term liabilities/equity ratio $[1,4,13]$.

3. Self-financeable growth rate (SFGR): describe a company's growth rate realizable from operatively generagted means without divestment and outside financing [3, 9, 15].
If the net sales revenue growth rates of the income statement (Figures 3-7. indicated in red) exceed the calculated growth rates, the firms included national economy sector can not meet its payment obligations, and financing capacity is upset and effective steps should be taken using the crisis management instruments.

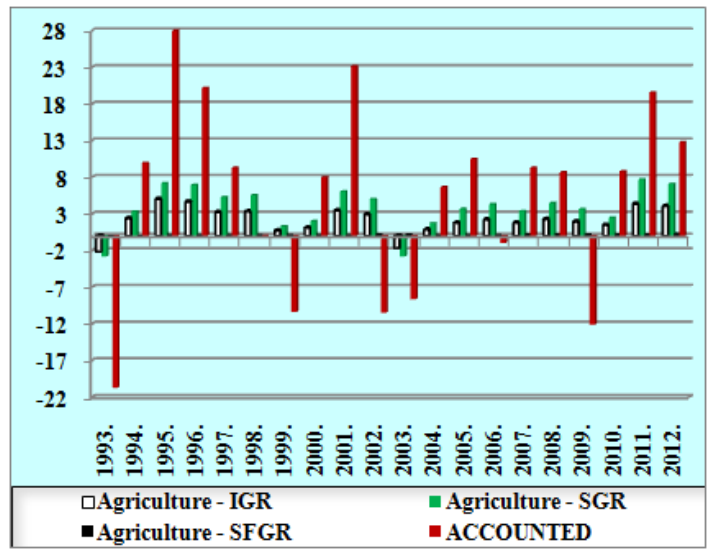

Figure 3a. The internal, sustainable, self-financeable and accounted for net sales growth rates of the AGRICULTURE branch (DOMESTIC majority ownership, in percent)

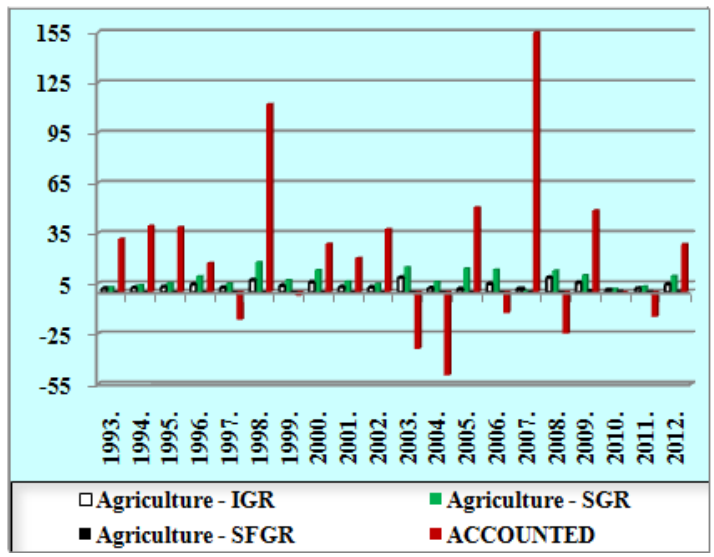

Figure 3b. The internal, sustainable, self-financeable and accounted for net sales growth rates of the AGRICULTURE branch (FOREIGN majority ownership, in percent)

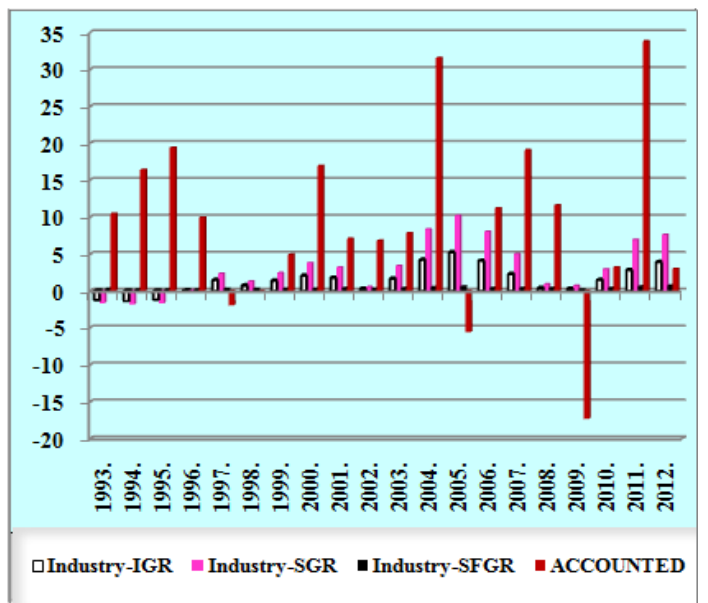

Figure 4a. The internal, sustainable, self-financeable and accounted for net sales growth rates of the INDUSTRY branch (DOMESTIC majority ownership, in percent) 


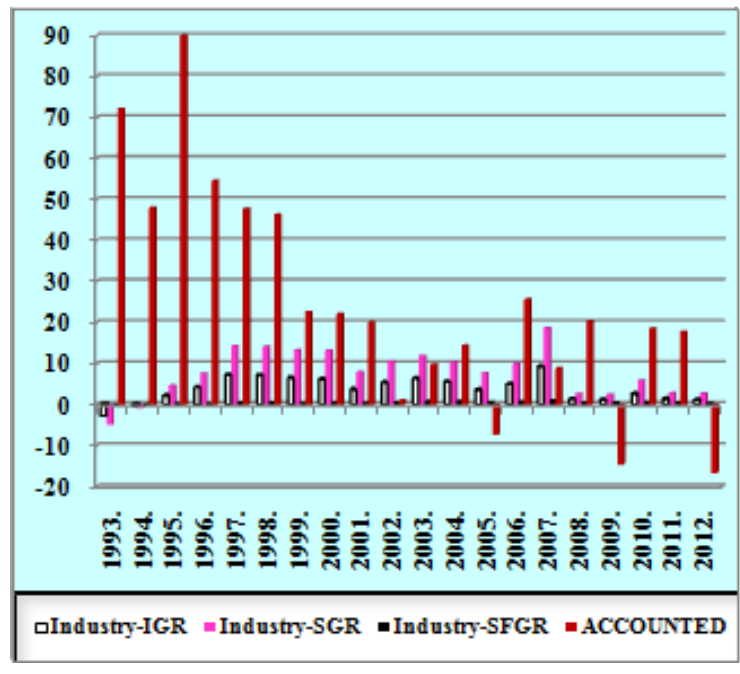

Figure $4 \boldsymbol{b}$. The internal, sustainable, self-financeable and accounted for net sales growth rates of the INDUSTRY branch (FOREIGN majority ownership, in percent)

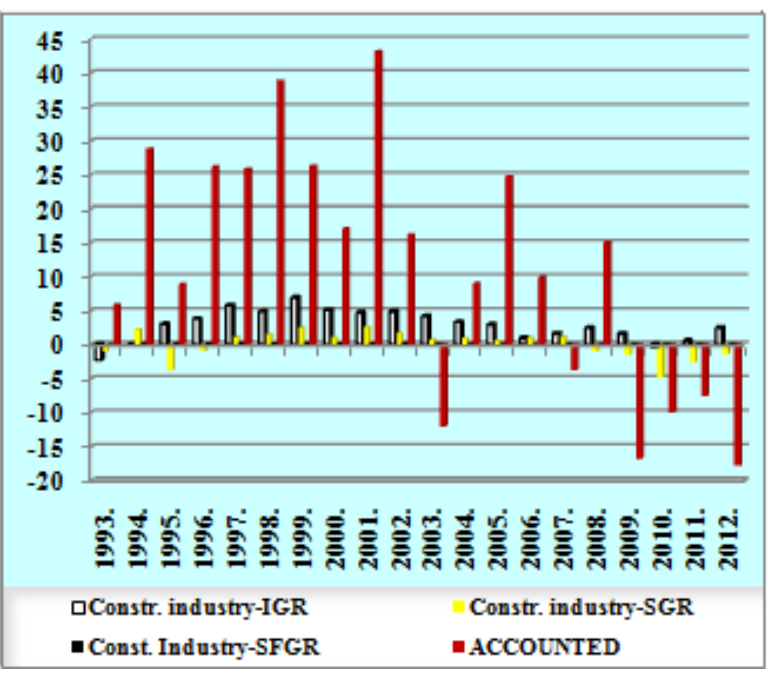

Figure 5a. The internal, sustainable, self-financeable and accounted for net sales growth rates of the CONSTRUCTION INDUSTRY branch (DOMESTICmajority ownership, in percent)

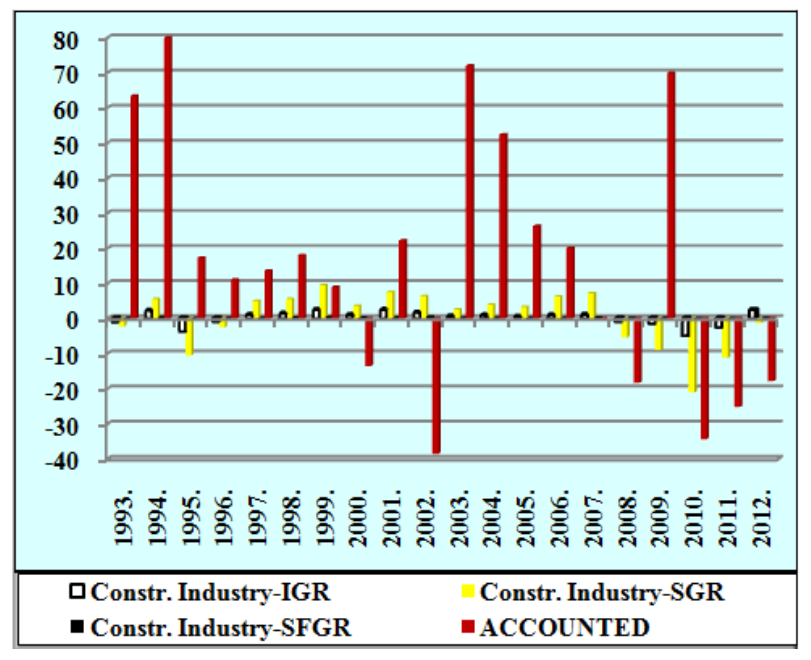

Figure 5b. The internal, sustainable, self-financeable and accounted for net sales growth rates of the CONSTRUCTION INDUSTRY branch (FOREIGN majority ownership, in percent)

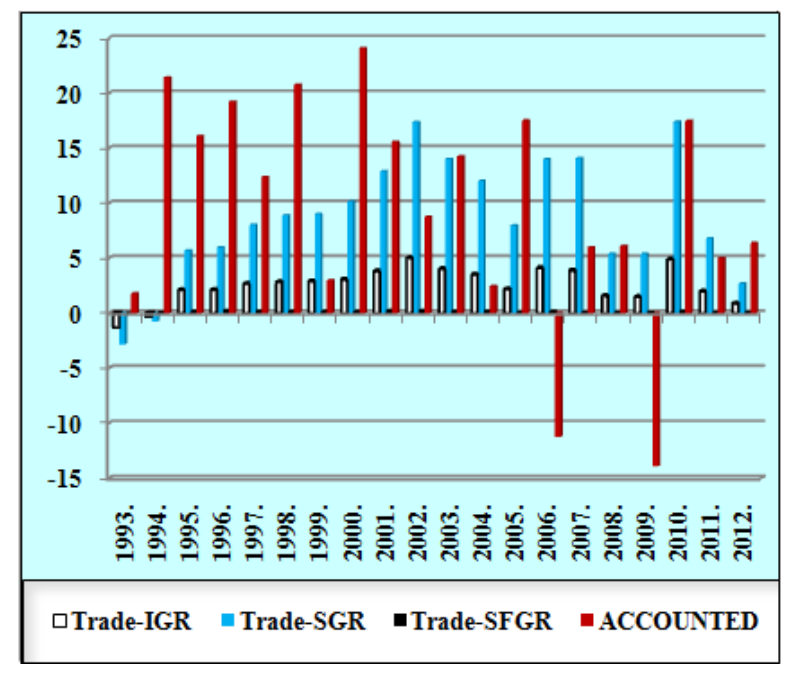

Figure 6a. The internal, sustainable, self-financeable and accounted for net sales growth rates of the TRADE branch (DOMESTIC majority ownership, in percent)

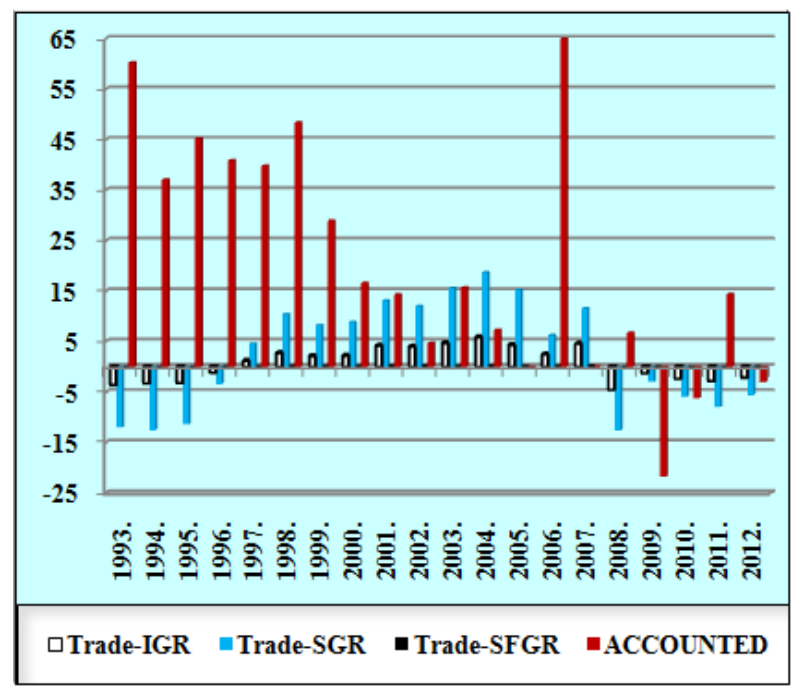

Figure $\mathbf{6 b}$. The internal, sustainable, self-financeable and accounted for net sales growth rates of the TRADE branch (FOREIGN majority ownership, in percent)

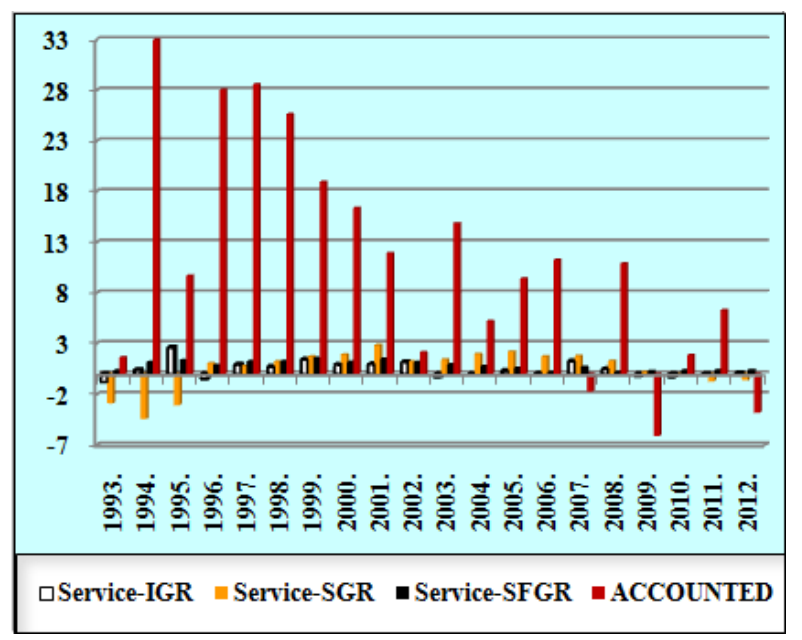

Figure 7a. The internal, sustainable, self-financeable and accounted for net sales growth rates of the SERVICE branch (DOMESTIC majority ownership, in percent) 


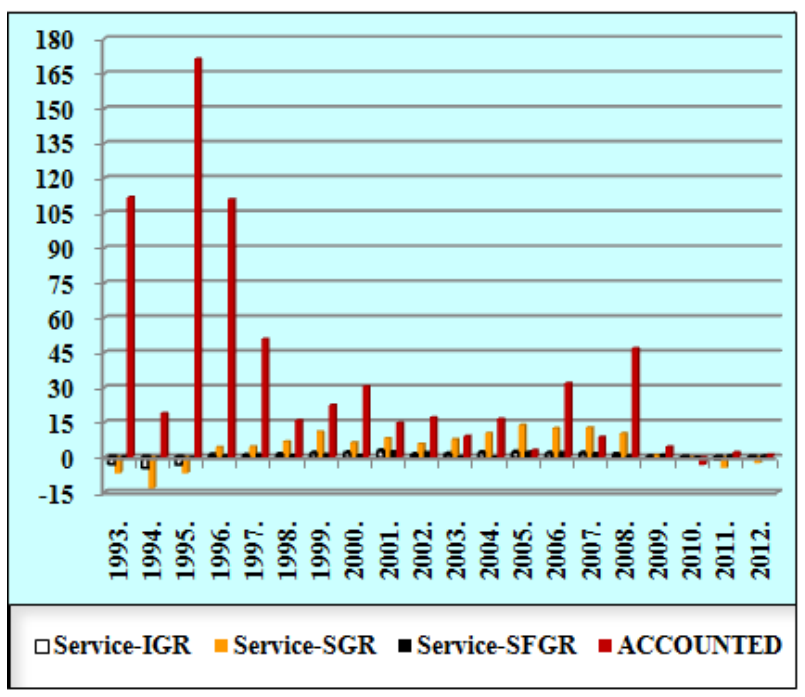

Figure $7 \boldsymbol{b}$. The internal, sustainable, self-financeable and accounted for net sales growth rates of the SERVICE branch (FOREIGN majority ownership, in percent)

The internal growth rate calculations to answer the question, we examined the branches of the economy have been produced to what extent sales revenue growth, and if it had been used exclusively retained profit. The Figures 3-7. show that the national economic sectors examined sales revenue would have been able to increase their retained profits is low, only a few percent level. The actual net sales growth rates (in red) are much higher, suggesting the forced sale. In addition, the internal growth rates hectic changed. A negative value indicates that it was not possible to increase sales revenue retained profit. In case the internal growth rate is less than the net sales revenue from the income statement according to the growth rate, so the latter external sources of funding (mostly foreign sources) been implemented. This is especially true in industry, construction, trade and services. I can see that could have been retained profits compared to more sales revenue than the recorded sales revenue (especially in recent years), the cause of which we see most of all the decline in market demand.

We can examine the sales revenue growth rate has also examined the economic sector that you want to keep the capital structure has been achieved. Figures 3-7. in the calculation of the final result is announced that the companies belonging to the sections examined what it would have produced a sales revenue growth, if it does not modify the source of their balance sheet structure (always considering the appropriate balance sheet items of the current year). The values of sustainable growth rates much greater variance than the internal values of growth rates. There are two directions are as extreme values are calculated:

1. The economic sectors as part of an investigation had (have) to produce one year to the next in order of 10-20\% revenue growth rate to maintain the capital structure achieved.

2. The number of significant negative sustainable growth rates, which means that revenue could not be stepped up in order retain the capital structure.

Despite the positive trend of net sales revenue adverse changes in the profitability problems in the operational management of national economic sectors. Therefore the profitability, liquidity and financing position (even further) analysis of the national economic sectors suggested several weaknesses. Have arisen on the weak signals of the crisis on growth. Have arisen on the weak signals of the crisis on growth. The growth crisis among listed weak signals - for this example - the forced sale of aggressive advertising. These financing companies were not able to solve the healthy capital structure is maintained. With the expansion and the fast rhythm of the asset due to reduced efficiency, managers have fallen under the spell of greatness rather than the profit orientation and do not pay enough attention to the liquidity of the assets fit the expiry date of structure of liabilities. The expansion of the fast rhythm and reduced the efficiency of the asset. Managers have fallen under the spell of greatness rather than the profit orientation and do not pay enough attention to the liquidity of the assets fit the expiry date of structure of liabilities. If the strong market competition and changes in market demand, the responsibility of management to seek the foresight, the permanent innovation and timely deduction of appropriate consequences. Management recognizes the growing crisis as early as possible preferably weak - signals, the more opportunities to correct the incorrect corporate development.

\begin{tabular}{|c|c|c|c|}
\hline Mode & HORIZONTAL & VERTIKAL & LATERAL \\
\hline INTERNAL & Sales expansion & Function expansion & Diversification \\
\hline \multicolumn{3}{|c|}{ THE INTERNAL FINANCING STRENGHT PRIMACY } \\
\hline EXTERNAL & $\begin{array}{c}\text { Acquisition of the companies with } \\
\text { the same profile }\end{array}$ & Integration \\
\hline \multicolumn{4}{|c|}{ COMBINED WITH INTERNAL FINANCING STRENGHT } \\
AND \\
EXTERNAL FINANCING CAPACITY
\end{tabular}

Figure 8. Possible ways of corporate growth Sources: [6]

Examining the database is only inkling as to what growth modes to choose the largest enterprises (primarily external growth, especially in the sales expansion combined with horizonal and vertical integration). Our recommendation is that the internal and external corporate growth mode (Figure 8.) does not exclude, but rather complement each other, 
especially a successful combination. The actual decisionmaking must take various sectoral and company-specific condition, especially in consideration of the management preferences, which are heterogeneous weighting the advantages different strategies.

\section{1. "We Have Managed Profitably While Paying Capable Stayed ?!"}

The business you can are viable if it is revenue-generating activities. The net revenue evolution of the we can judge the potential for profitability main source. In Figures 9 and 10 illustrate the net sales revenue growth rates of development of domestic and foreign private ownership broken down 1993 to 2012 period. In the period 1993-2012 the greatest firms in a database encompassing National economic sectors evolution of net sales revenue for 2003 and 2009, the year of significant decline occurred. The four branches of the national economy DOMESTIC last 2012 years of decline in the investigation, in contrast with the exception of the foreign branches of the national economy, industry and trade.

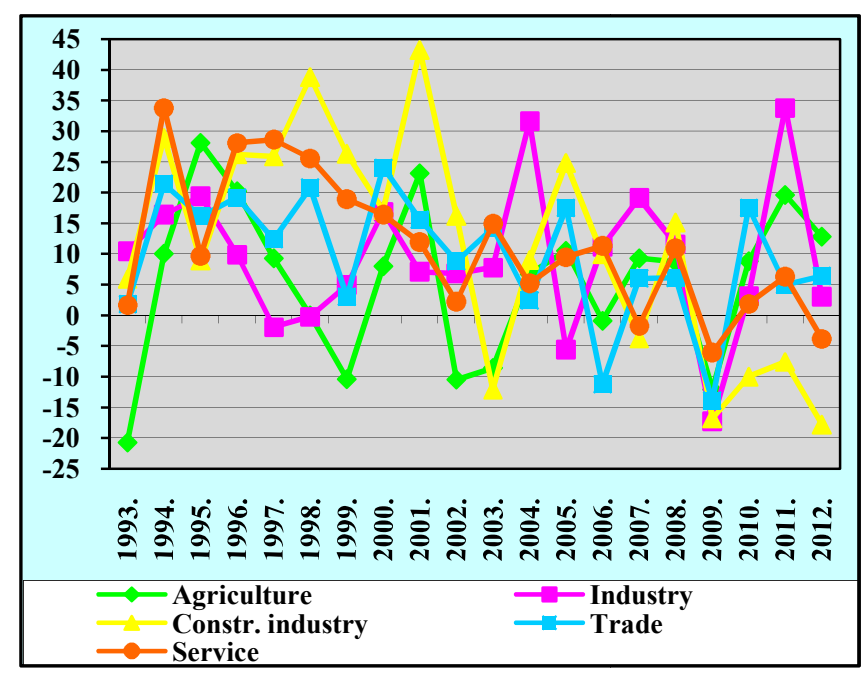

Figure 9. The Hungarian TOP 5000 - NET SALES REVENUE GROWTH rates (DOMESTIC majority ownership, a percentage of the previous year)

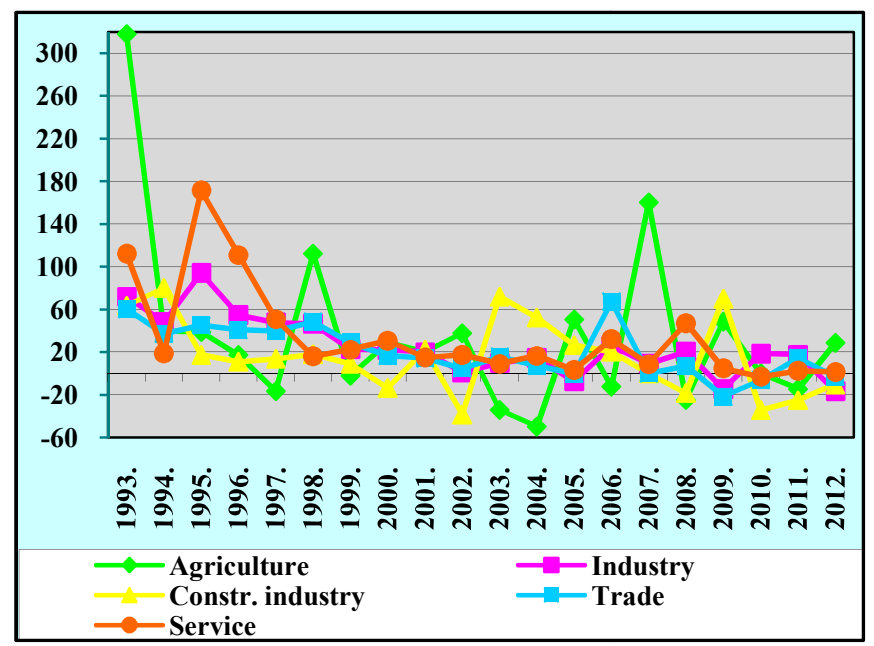

Figure 10. The Hungarian TOP 5000 - NET SALES REVENUE GROWTH rates(FOREIGN majority ownership, a percentage of the previous year)
Increase in sales revenue owners (also) for the direct benefit specializing businesses encompassing sections considered of value creation source, but this is only true if the sale proceeds of the national economic sectors are relatively high margins would be achieved by either the operation or the corporation tax paid after. The Figure 11-12. includes operating income-generating capacity of the national economic sectors.

The evolution of operating profitability (Figure 11-12.) in the following three comments.

1. The negative value of the largest business associations sections unprofitable operation indicates, that the operating expenses exceed the net sales proceeds.

2. Despite seeing positive operating profit margin, they can both relatively very low. Thus, the largest business associations sections advantage of the possibility of reducing the corporate tax base.

3. Most of the negative values at the beginning of the test interval, and mostly foreign-owned branches of national economic we find (tax relief and tax relief received).

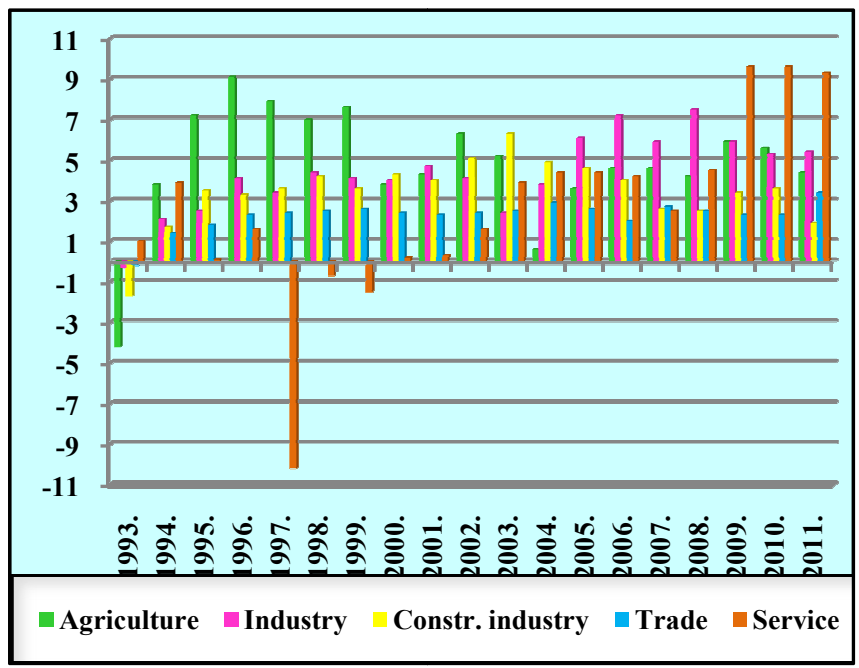

Figure 11. The Hungarian TOP 5000 - OPERATING INCOME/NET SALES REVENUE rates (DOMESTIC majority ownership, in percent)

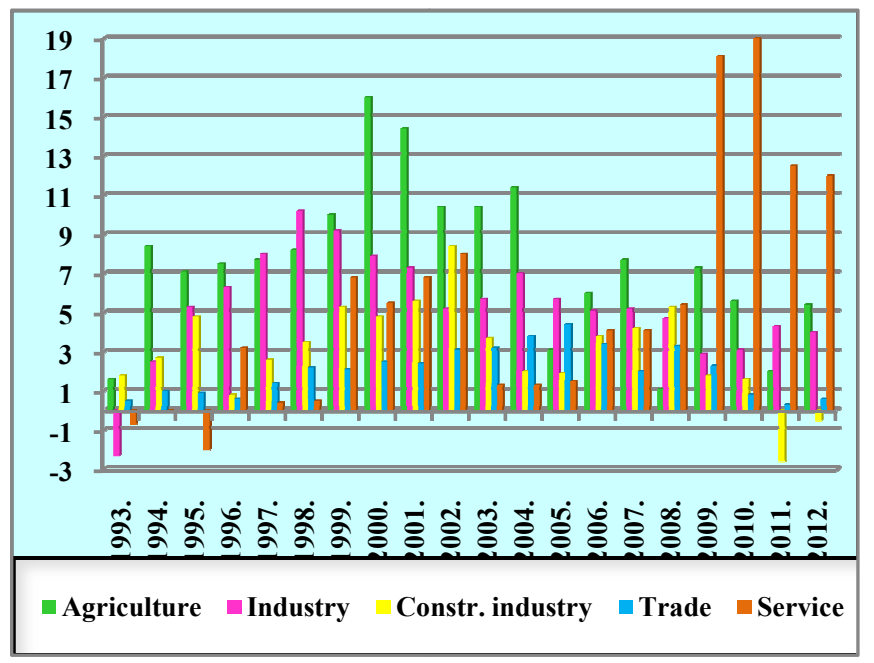

Figure 12. The Hungarian TOP 5000 - OPERATING INCOME/NET SALES REVENUE rates (FOREIGN majority ownership, in percent) 
Changes in the net profitability (Figure 13-14.) indicates that the branchen dividends translates what portion of the sales revenue, on loan repayment and/or new investment. In recent years, the net sales revenue from the sections are retained and used a small percentage of total operating costs, interest and after deduction of income tax. However, it should be noted that only the losses seen at the beginning of the test interval (negative operating profit margins is due to the value).

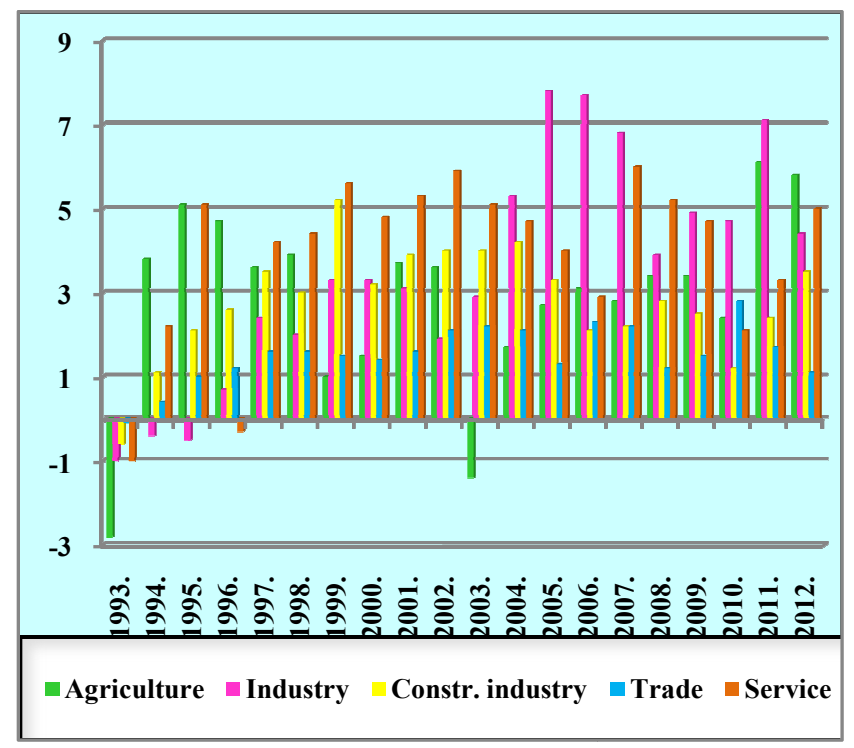

Figure 13. The Hungarian TOP 5000 - AFTER-TAX PROFIT/NET SALES REVENUE rates (DOMESTIC majority ownership, in percent)

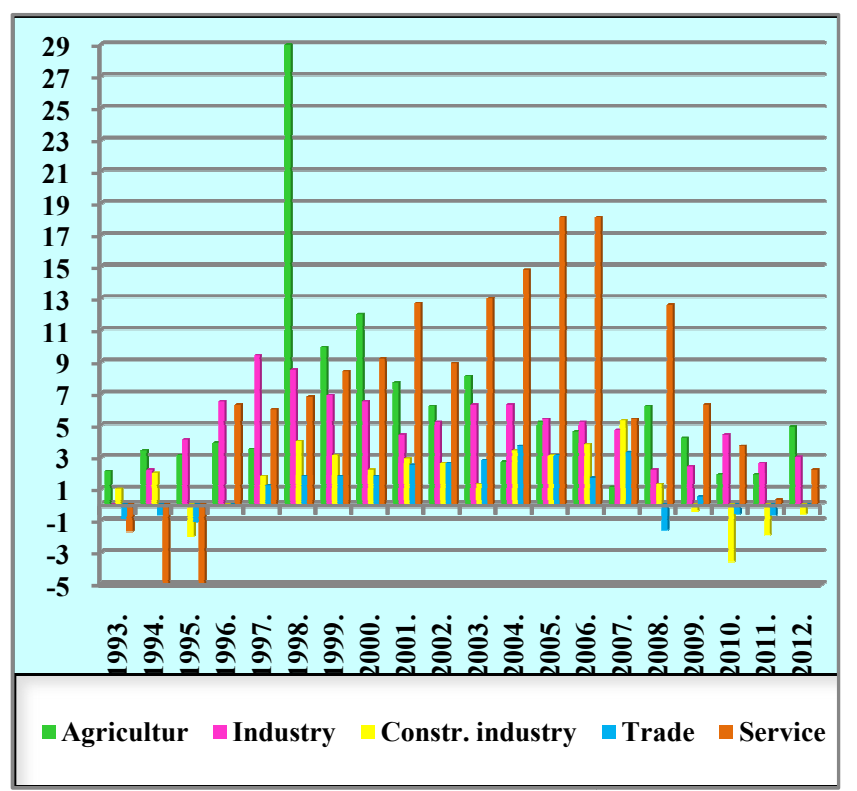

Figure 14. The Hungarian TOP 5000 - AFTER-TAX PROFIT/NET SALES REVENUE rates (FOREIGN majority ownership, in percent)

Indicative of profitability of pure profit retention rates (Figure 15-16.), the recognized standards of self-financing. The domestic ownership businesses encompassing national economic sectors - were much more balanced self-financing - compared to foreign-owned businesses that include sections. Is welcome the fact that - with some exceptions the vast majority of the national economic sectors tried to work with 'self-financing', ie retained a significant portion of their profits after tax dodging the dividend payment, which can be significant based on internal growth (would ed) to achieve. (The profit retention rate of profit/net profit according to the balance calculated calculation. If the dividend payout ratio exceeds 100 percent, then companies belonging to the nation's economic branch retained earnings also engaged the services of a dividend payment of. The current year thus the profit retention rate value will be negative.) The negative sign is a clear indication that the domestic and foreign agriculture, trade, services and construction industrial sector was not self-financing.

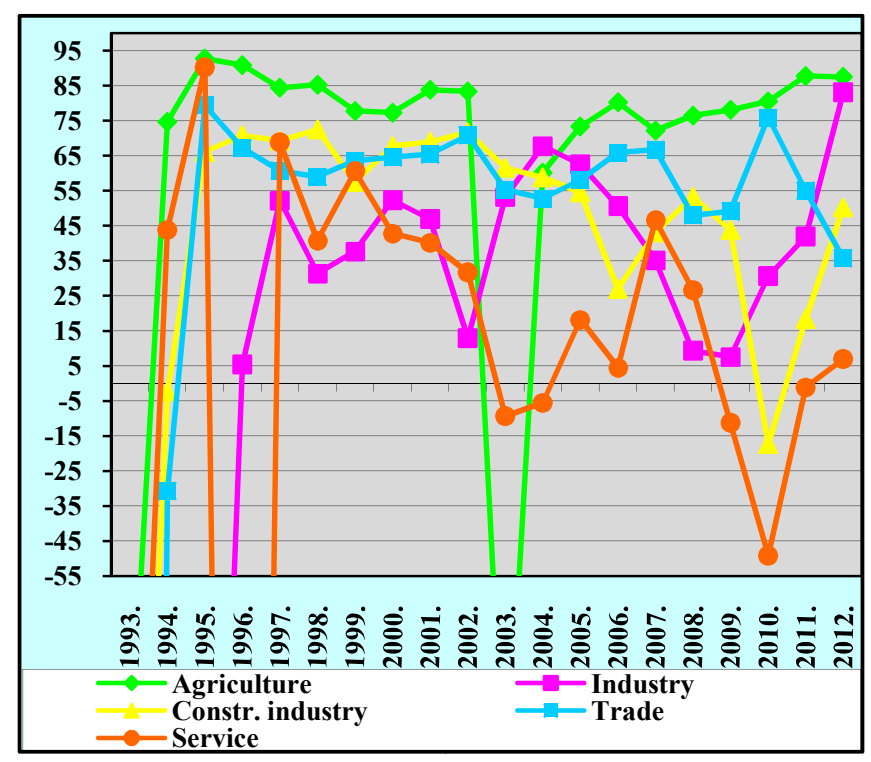

Figure 15. The Hungarian TOP 5000 - BALANCE SHEET PROFIT/AFTER-TAX PROFIT rates (DOMESTIC majority ownership, in percent)

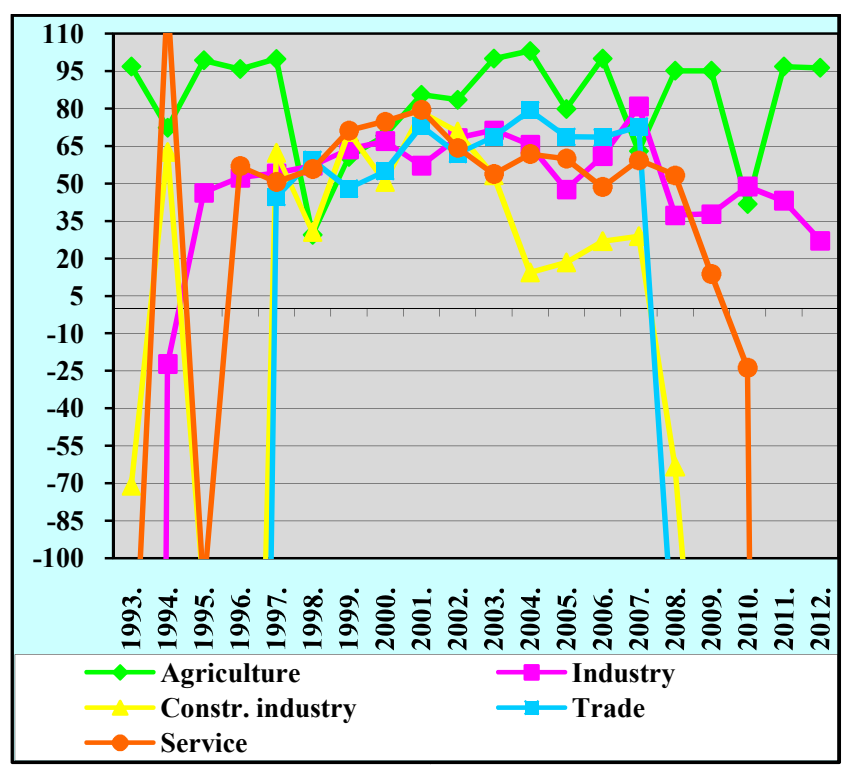

Figure 16. The Hungarian TOP 5000 - BALANCE SHEET PROFIT/AFTER-TAX PROFIT rates (FOREIGN majority ownership, in percent) 


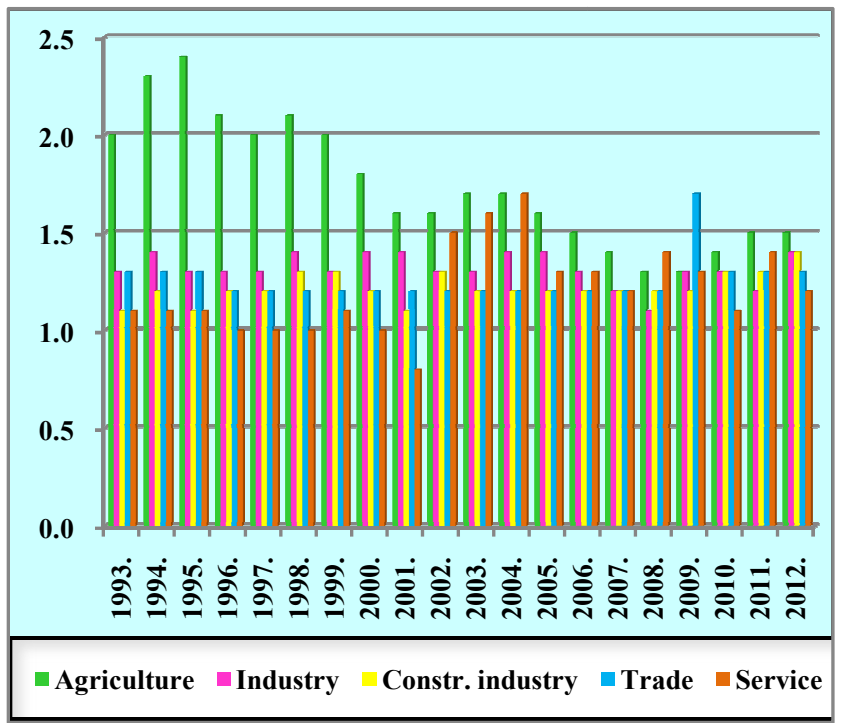

Figure 17. The Hungarian TOP 5000 - CURRENT ASSETS/CURRENT LIABILITIES rates (DOMESTIC majority ownership, in percent)

After examining three levels of profitability we come to analyze liquidity. Changes in the examined national economic sectors of the liquidity of Table 5 and Figure 17-18. show. All five of the national economy sectors in the shortterm liabilities covered in current assets (including working capital values are positive, except the domestic and foreign- owned service and agriculture economy sectors), but the favorable (or bank debt rating under) 2 or greater value -20 years time horizon - we hardly find. The reason we see the composition of current assets, because they represented a significant proportion of their current assets have 'purchased and own produced inventories' and 'receivables'.

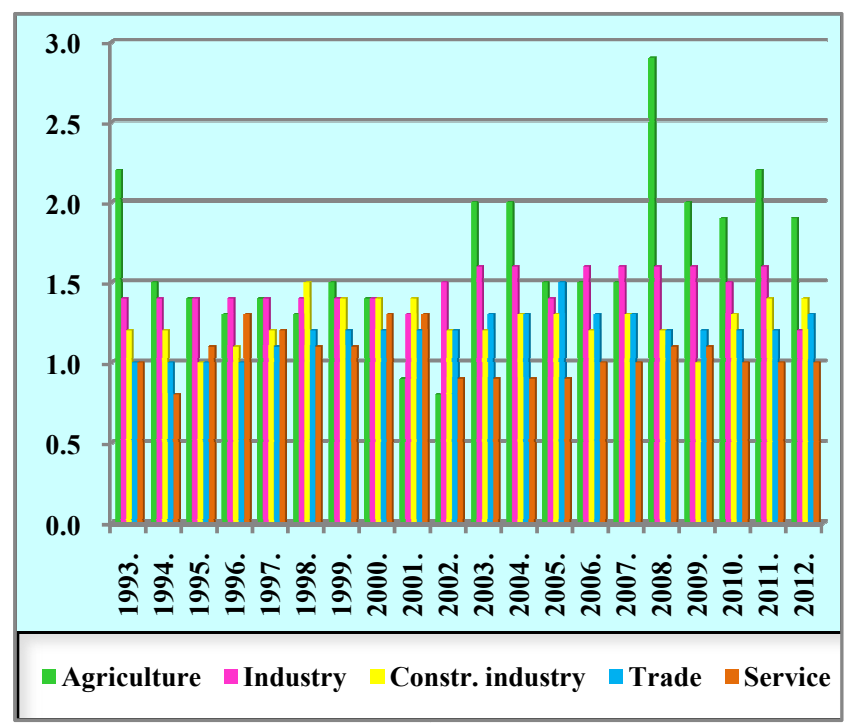

Figure 18. The Hungarian TOP 5000 - CURRENT ASSETS/CURRENT LIABILITIES rates (FOREIGN majority ownership, in percent)

Table 5. The Hungarian TOP 5000 - WORKING CAPITAL (DOMESTIC and FOREIGN majority ownership, in thousend HUF)

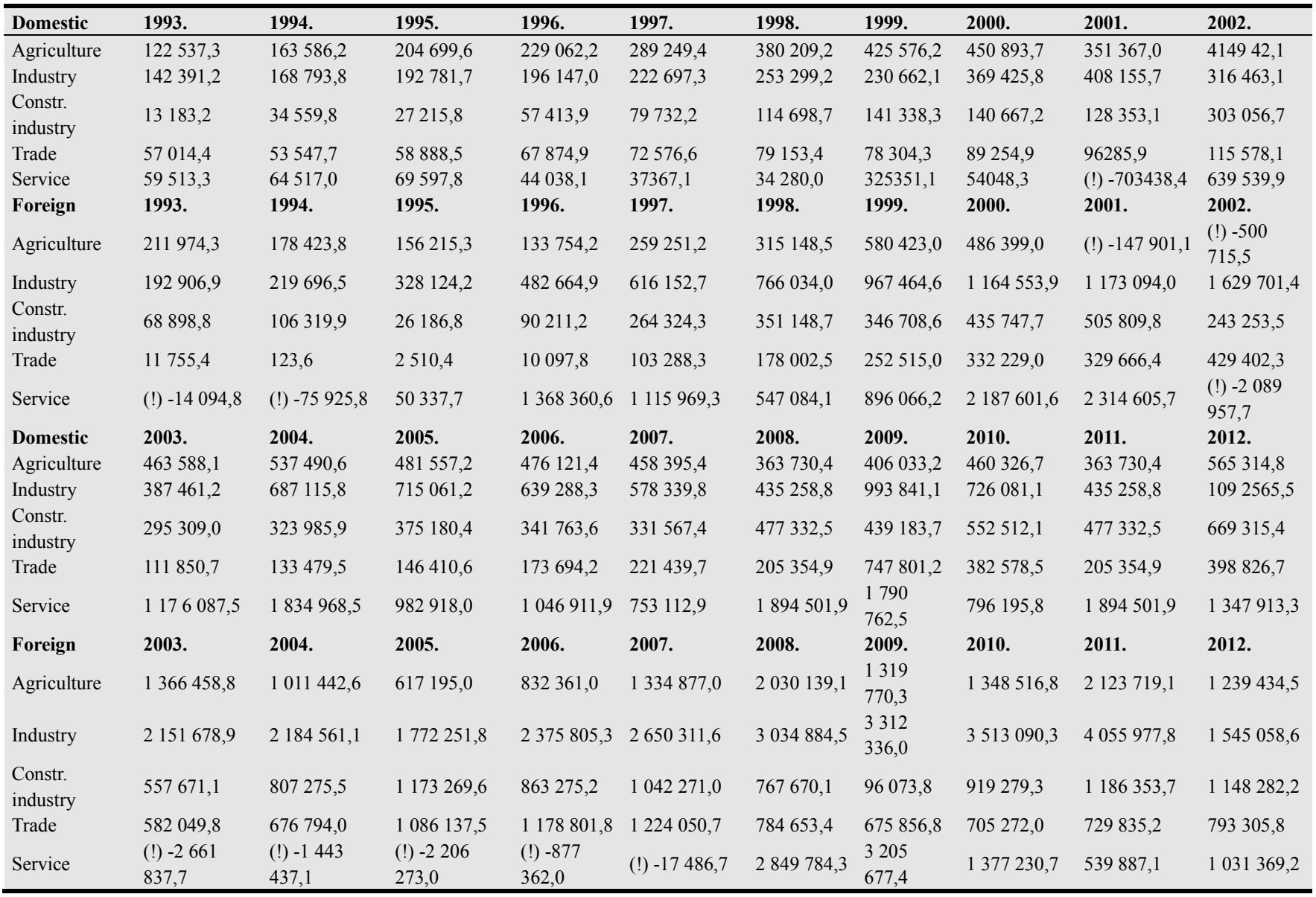


In Figure 19-20. we see that in the domestic agricultural sector half of all current assets inventory. This is in the last quarter of the examination time horizon roughly $1 / 3$ of the in foreign-owned service sector, but the number of foreignowned sector is lower, which is a favorable rating. In appendix 10 we see that the larger the size of receivables, but this is a very high rate of customer receivables more inventoriesl, also represent in total current assets! Significant change is not made, and thus did not improve the static liquidity. If you believe this even further, then to the conclusion that companies belonging to the national economic sectors considerable working capital financed operations, while it was not liquid capital.

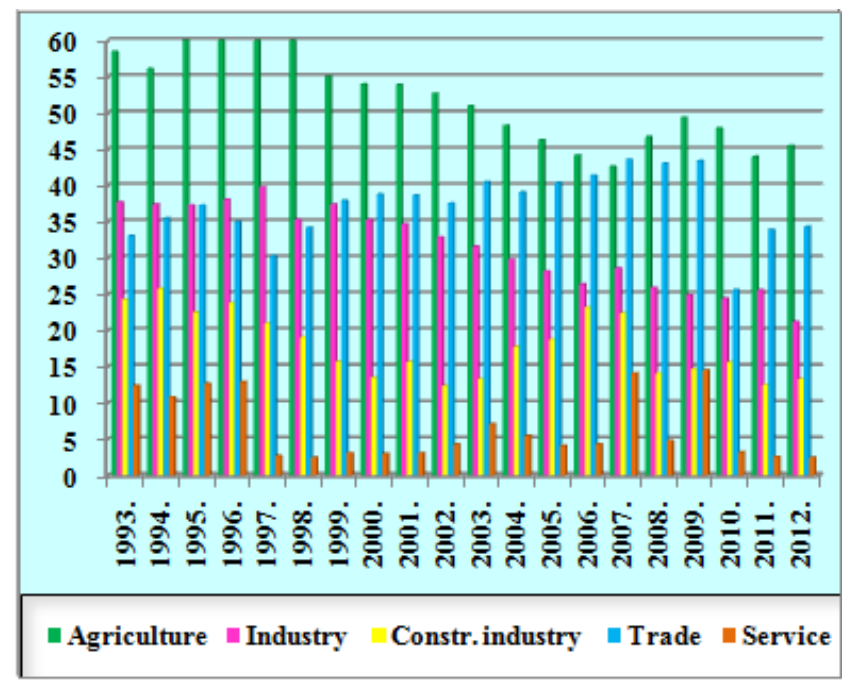

Figure 19: The Hungarian TOP 5000 - INVENTORIES/CURRENT ASSETS rates (DOMESTIC majority ownership, in percent)

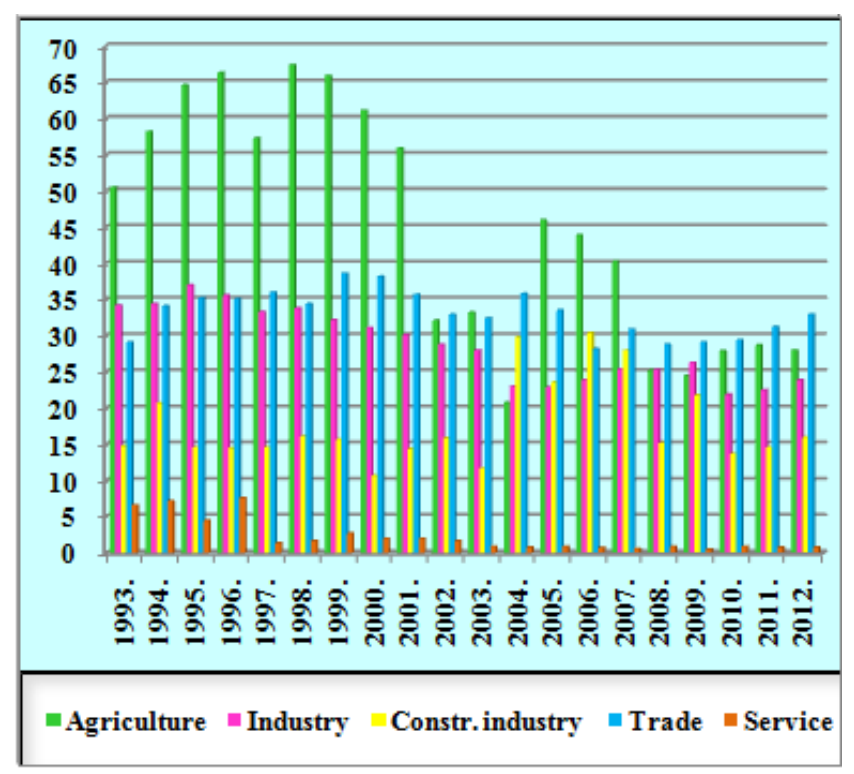

Figure 20. The Hungarian TOP 5000 - INVENTORIES/CURRENT ASSETS rates (FOREIGN majority ownership, in percent)

So far, in In summary is not only the low profitability and the unfavorable solvency threat to ownership (value) objectives realization, but the unstable financing, indebtedness, assets, various types of significant cash deposit time, which could adversely affect the cash flow and they are all adversely affect the (near) future growth prospects. These will be analyzed in the next section.

\subsection{The Objective of Shareholdervalue Creation?!}

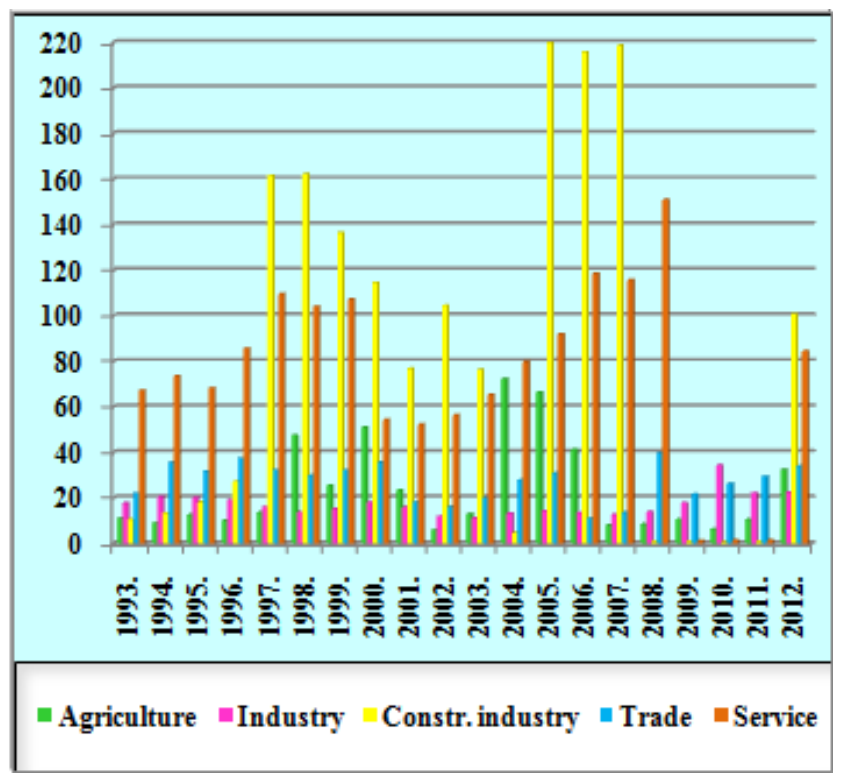

Figure 21. The Hungarian TOP 5000 - DEBT/EQUITY rates (DOMESTIC majority ownership, in percent)

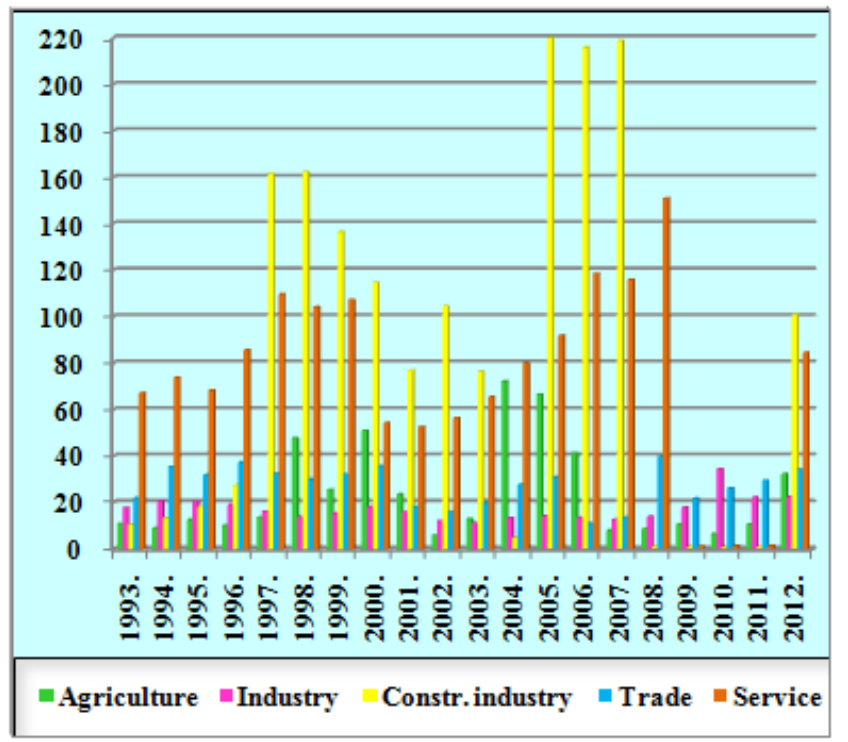

Figure 22. The Hungarian TOP 5000 - DEBT/EQUITY rates (FOREIGN majority ownership, in percent) 


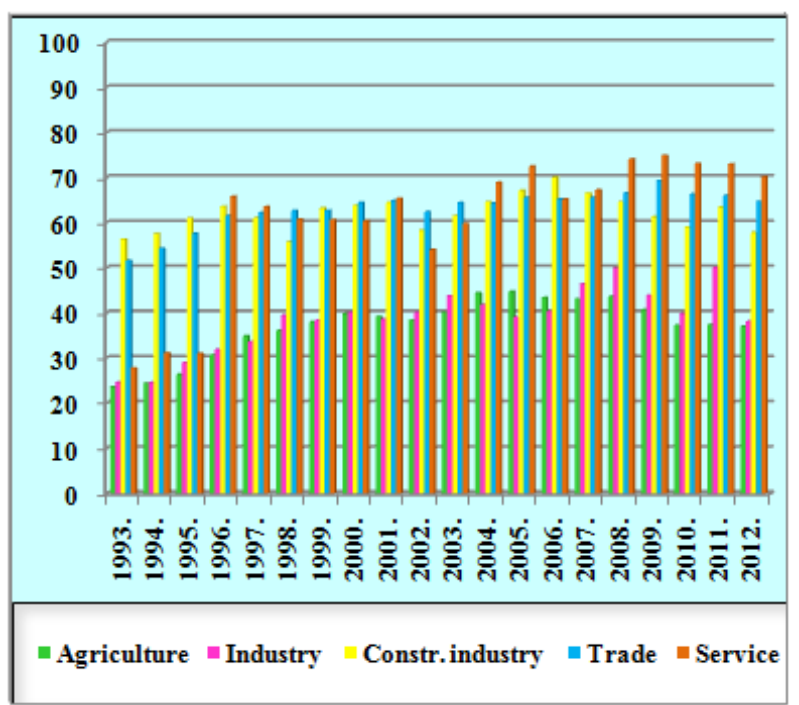

Figure 23. The Hungarian TOP 5000 - TOTAL LIABILITIES/TOTAL, SOURCES rates (DOMESTIC majority ownership, in percent)

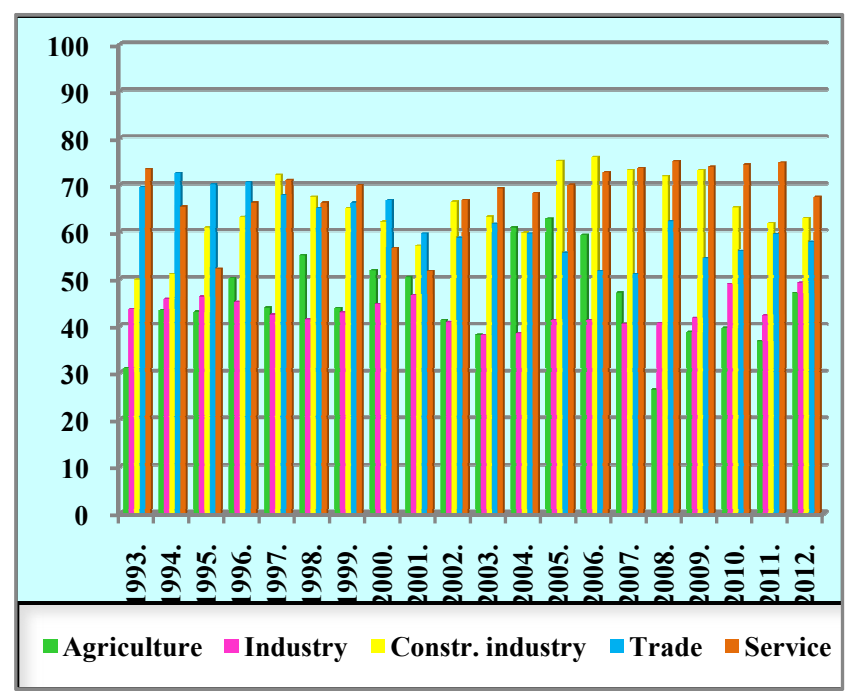

Figure 24. The Hungarian TOP 5000 - TOTAL LIABILITIES/TOTAL SOURCES rates (FOREIGN majority ownership, in percent)

The owners for value creation occurs when they realize a higher return on investments by comparison with a given market and business ockázat. These investments are to be financed on a long-term one for years, which made the ownership and/or creditors of capital. Shareholder value creation does not matter to what extent the carrying debt companies, industries - in this case the sections. This capital structure in the evolution of values illustrate that the socalled. Is an analysis of "funding golden rule" justice too, and says, "Do not pick up the foreign capital the more than their own capital!" In other words: "As far as financing your decisions, the debt ratio is not greater than $1 / 2 "$. In Figure 2122 , we see that the construction industry and service sector is committed equity capital in excess of debt, so the foregoing indebted companies, and are not considered financially strong companies. However, in the domestic and foreign branches in recent years with regard to "normalize the situation somewhat", because we value less than 100 percent. If long-term liabilities side of the balance we take into consideration the total short-term liabilities, and all foreign sources the resulting is compared to all sources, the in Figure 23-24. both domestic and foreign-owned service and the commercial sector, $70-80 \%$ of total foreign liabilities. Indirectly, this can be the proportion of ownership capital (indicated in the figure $\%$ is the difference between $100 \%$ and the column diagram), which in turn implies the following two things:

- On the one hand the owners' risk willingness, or just assume the business risk even half as well;

- Secondly, the size of its capital strength, as evidenced by the owners that is less than $50 \%$ shareholding, but not thereby decreasing the risk of financing. Consequently, all of the additional debt assumed only makes sense if

1. solve the management/business operations inherent problems;

2. comply with the profitability-efficienc requirements;

3 . coupled with growth perspective.

Let's look a little realization of that requirement 1.! Figure 25. illustrates the exploration potential of the management/business operations inherent problems.

The short-term financing, and so - again - level of the liquidity situation we can conclude both from the fact that the size of the claims extent to cover short-term liabilities, on the other hand, "Will the (customer) recovery of the money to fund the supplier's liabilities?" questions to the Appendix 5., we find for each of the five national economic sectors in the shortterm liabilities more than half of the claim. This is not correct! In Appendix 2-3. also now see that the recovery time of the customer claims exceeds settlement date of the liabilities to suppliers - particularly in the final years of the test time horizon - such as claims from customers recoveries can not be funded by the suppliers of liabilities that threatens the seamless management. However, these values at the beginning of the test time horizon even higher.

The service and the construction sector have achieved extremely high values. Should not be a (customer) outstandings from the short-term (suppliers) liabilities to meet, the largest firms other funding sources had to use, and it's a positive case of short-term foreign funding sources, while unfavorable(er) case, including long-term foreign capital occurred.

Here we again raised the question: If the business of shortterm financing problems arose, the company in the long run how the value created for shareholders? - To answer this question, you should also take into consideration the following results. 


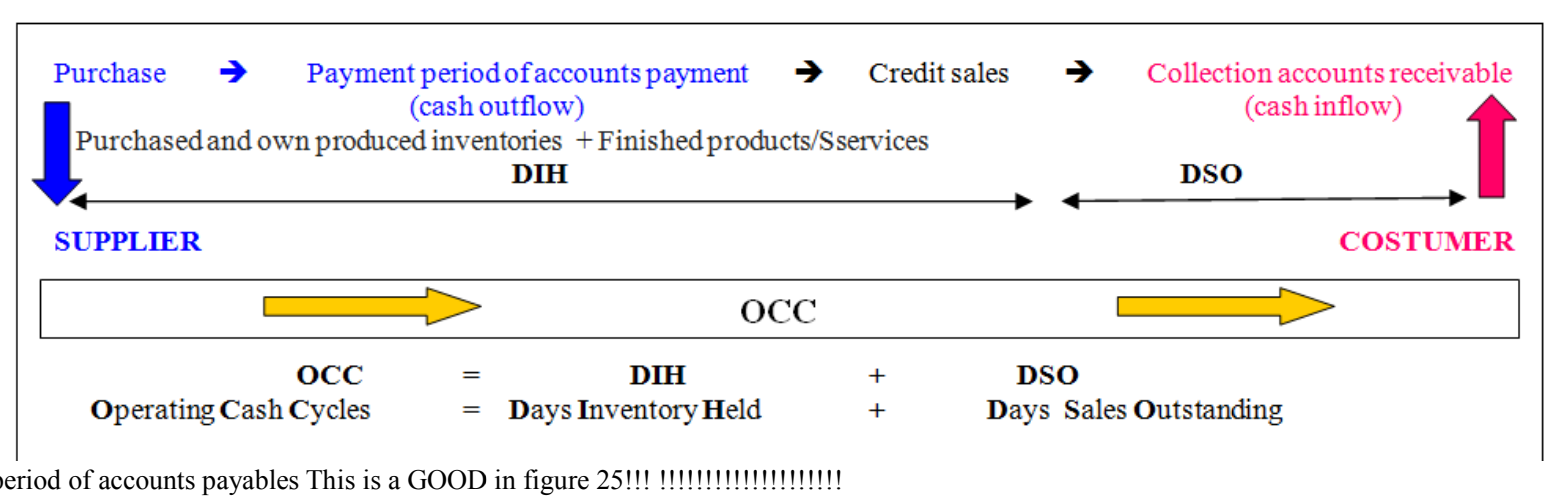

Payment period of accounts payables This is a GOOD in figure 25!!! !!!!!!!!!!!!!!!!!!!

Figure 25. The contests of the operating cash cycle of the activity and the cash flow Source: [7]

Table 6. contains evolution of the ROA (Return on Assets) rates, which shows the after-tax profit return on total assets. If the ROA is negative, it indicates that the company is operating at a loss. Here, too, a very low values of predominantly $10 \%$. If these values we decompose ROA two ingredients, the net profitability (Figure 25. and 27.) and asset-efficiency (net sales revenue/total assets), it is even more we see problems or strenghts of the sector's operational functioning. For this example, we compare the domestic construction industry branch in 2009 and 2012 ROA ratios components as follows [16]

2012: $\mathrm{ROA}=4.93 \%$, which is $3.54 \%$ of net profitability and 1.3 asset-efficiency achieved.

2009: $\mathrm{ROA}=3.62 \%$, which is $2.49 \%$ and net profitability of 1.45 asset-efficiency achieved.

Table 7. shows the ROE (Return on Equity) rates of evolution, which refers to the after-tax profit return on equity (ownership) capital. Unfortunately, the owners of a rate of return falls far short years of the review period the value of the current central bank base rate! In addition, the low return on shareholder equity financing ratio is relatively high and relatively low ROA value is achieved. Again, for the sake of example we compare the domestic construction branch in 2009 and 2012 ROE rates of the following components [16]:

2012. $\mathrm{ROE}=14 \%$, which is $3.54 \%$ net profitability, asset efficiency of 1.3 and 2.94 financing ratio achieved 2009: $\mathrm{ROE}=1198 \%$, which reached $2.49 \%$ net profitability, 1.45 asset efficiency and 3.56 funding ratio. So we can conclude that the domestic construction branch of the more favorable ROE was achieved more favorable net profitability, the ability to generate revenue assets could not be improved, while still relatively high, but decreasing the assets financed with large foreign source. (In 2009, approximately 2.5 units of equity foreign sources, while in 2012, approx. twice as many foreign sources reached, indicating the reduction of foreign fund raising.)

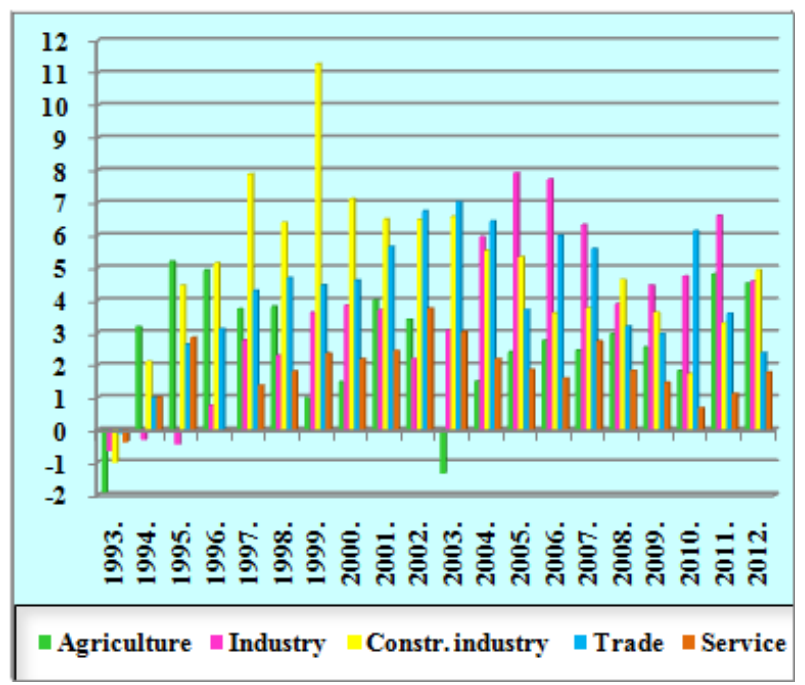

Figure 26. The Hungarian TOP 5000 - ROA rates (DOMESTIC majority ownership, in percent)

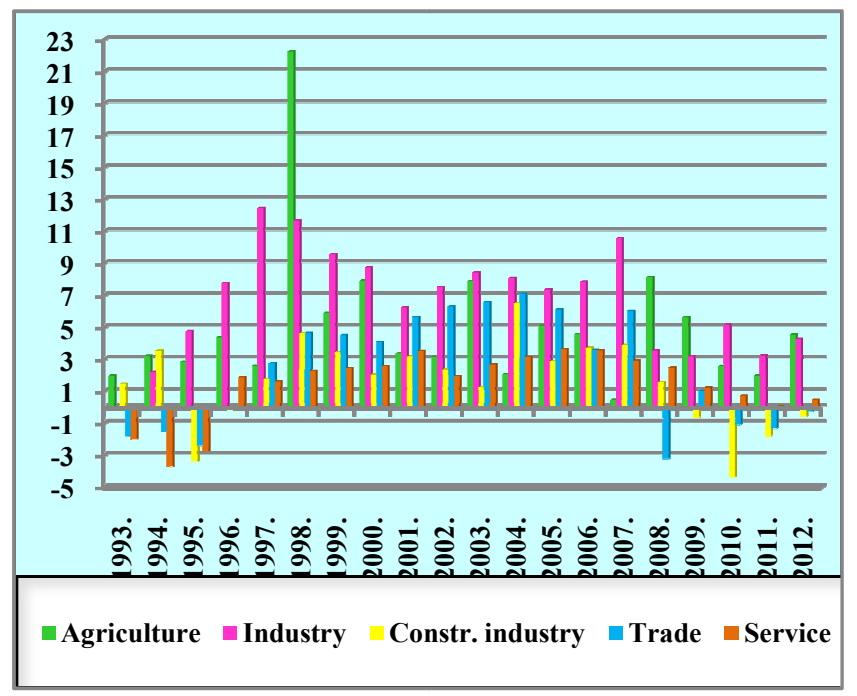

Figure 27. The Hungarian TOP 5000 - ROA rates (FOREIGN majority ownership, in percent) 


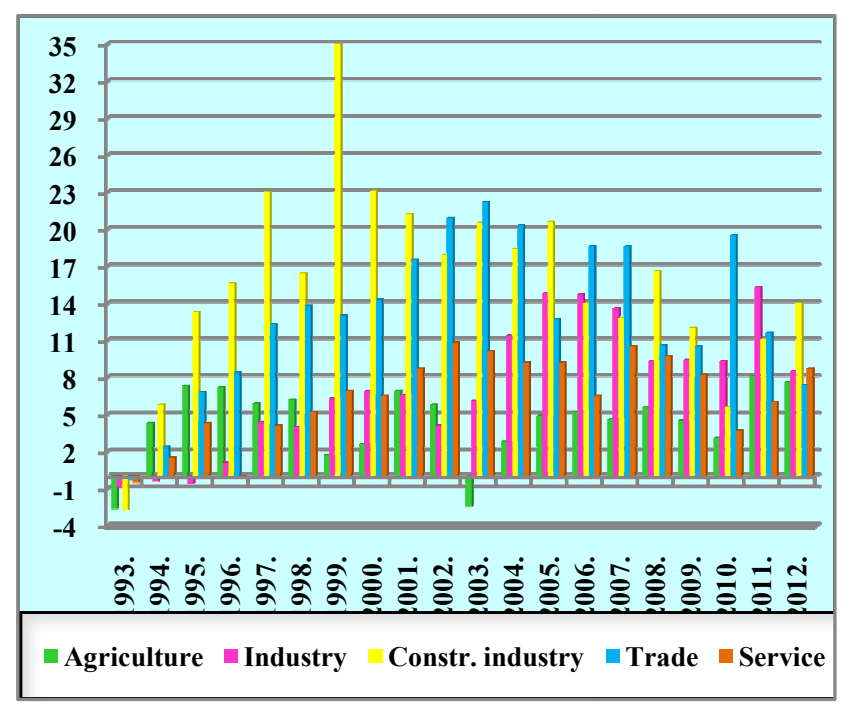

Figure 28. The Hungarian TOP 5000 - ROE rates (DOMESTIC majority ownership, in percent)

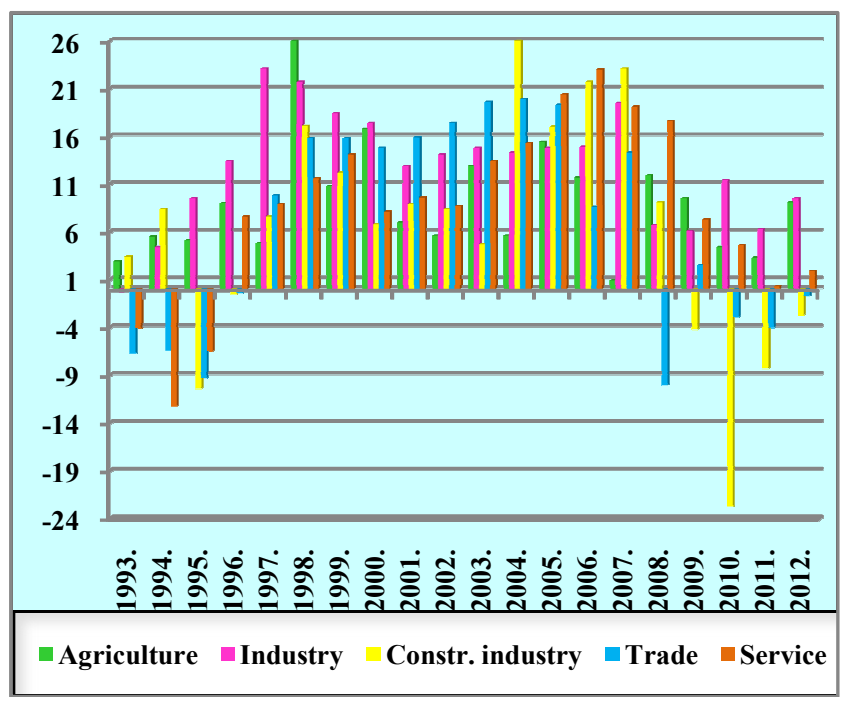

Figure 29. The Hungarian TOP 5000 - ROE rates (FOREIGN majority ownership, in percent)

Table 6. The DUPONT Model (ROA)

\begin{tabular}{|c|c|c|c|c|c|c|c|c|c|c|c|c|c|c|c|c|c|c|c|c|}
\hline Domestic & 1993 & 1994 & 1995 & 1996 & 1997 & 1998 & 1999 & 2000 & 2001 & 2002 & 2003 & 20042 & 2005 & 20062 & 20072 & 20082 & 20092 & 2010 & 2011 & 2012 \\
\hline \multicolumn{21}{|l|}{ AGRICULTURE } \\
\hline ROA (\%) & $-1,9$ & 3,2 & 5,2 & 4,9 & 3,7 & 3,8 & 1,0 & 1,5 & 4,0 & 3,4 & $-1,3$ & 1,5 & 2,4 & 2,8 & 2,5 & 3,0 & 2,5 & 1,8 & 4,8 & 4,5 \\
\hline Net Sales/Total Assets & 0,7 & 0,9 & 1,0 & 1,1 & 1,0 & 1,0 & 0,9 & 1,0 & 1,1 & 1,0 & 0,9 & 0,9 & 0,9 & 0,9 & 0,9 & 0,9 & 0,8 & 0,8 & 0,8 & 0,8 \\
\hline Net profit/Net Sales (\%) & $-2,8$ & 3,8 & 5,1 & 4,7 & 3,7 & 3,9 & 1,1 & 1,5 & 3,7 & 3,6 & $-1,5$ & 1,7 & 2,7 & 3,1 & 2,8 & 3,4 & 3,4 & 2,4 & 6,1 & 5,8 \\
\hline \multicolumn{21}{|c|}{ INDUSTRY } \\
\hline ROA (\%) & $-0,7$ & 0,3 & $-0,5$ & 0,8 & 2,8 & 2,3 & 3,6 & 3,8 & 3,7 & 2,2 & 3,1 & 6,0 & 7,9 & 7,7 & 6,3 & 3,9 & 4,5 & 4,7 & 6,6 & 4,6 \\
\hline Net Sales/Total Assets & 0,7 & 0,8 & 0,9 & 1,0 & 1,2 & 1,2 & 1,1 & 1,2 & 1,2 & 1,2 & 1,1 & 1,1 & 1,0 & 1,0 & 0,9 & 1,0 & 0,9 & 1,0 & 0,9 & 1,0 \\
\hline Net profit/Net Sales (\%) & $-1,0$ & $-0,4$ & $-0,5$ & 0,7 & 2,4 & 2,0 & 3,3 & 3,3 & 3,1 & 1,9 & 2,9 & 5,3 & 7,8 & 7,7 & 6,8 & 3,9 & 4,9 & 4,7 & 7,1 & 4,4 \\
\hline \multicolumn{21}{|c|}{ CONSTRUCTION INDUSTRY } \\
\hline ROA $(\%)$ & $-1,0$ & 2,1 & 4,5 & 5,1 & 7,9 & 6,4 & 11,3 & 7,1 & 6,5 & 6,5 & 6,6 & 5,5 & 5,3 & 3,6 & 3,8 & 4,6 & 3,6 & 1,7 & 3,3 & 4,9 \\
\hline Net Sales/Total Assets & 1,7 & 2,0 & 2,1 & 2,0 & 2,2 & 2,1 & 2,2 & 2,2 & 1,7 & 1,6 & 1,6 & 1,3 & 1,6 & 1,7 & 1,7 & 1,7 & 1,5 & 1,4 & 1,4 & 1,4 \\
\hline Net profit/Net Sales (\%) & $-0,6$ & 1,1 & 2,1 & 2,6 & 3,5 & 3,0 & 5,2 & 3,2 & 3,9 & 4,0 & 4,0 & 4,2 & 3,3 & 2,2 & 2,2 & 2,8 & 2,5 & 1,2 & 2,4 & 3,5 \\
\hline \multicolumn{21}{|c|}{ TRADE } \\
\hline ROA (\%) & $-0,1$ & 1,0 & 2,6 & 3,1 & 4,3 & 4,7 & 4,5 & 4,6 & 5,7 & 6,8 & 7,0 & 6,4 & 3,7 & 6,0 & 5,6 & 3,2 & 3,0 & 6,1 & 3,6 & 2,4 \\
\hline Net Sales/Total Assets & 2,2 & 2,6 & 2,7 & 2,5 & 2,7 & 3,0 & 2,9 & 3,3 & 3,4 & 3,2 & 3,2 & 3,0 & 2,8 & 2,7 & 2,6 & 2,7 & 2,0 & 2,2 & 2,1 & 2,2 \\
\hline Net profit/Net Sales (\%) & $-0,1$ & 0,4 & 1,0 & 1,2 & 1,6 & 1,6 & 1,5 & 1,4 & 1,6 & 2,1 & 2,2 & 2,1 & 1,3 & 2,3 & 2,2 & 1,2 & 1,5 & 2,9 & 1,7 & 1,1 \\
\hline \multicolumn{21}{|c|}{ SERVICE } \\
\hline ROA (\%) & $-0,4$ & 1,0 & 2,8 & $-0,1$ & 1,4 & 1,8 & 2,4 & 2,2 & 2,4 & 3,7 & 3,0 & 2,2 & 1,9 & 1,6 & 2,7 & 1,8 & 1,5 & 0,7 & 1,1 & 1,8 \\
\hline Net Sales/Total Assets & 0,4 & 0,5 & 0,6 & 0,3 & 0,3 & 0,4 & 0,4 & 0,5 & 0,5 & 0,6 & 0,6 & 0,5 & 0,5 & 0,6 & 0,5 & 0,4 & 0,3 & 0,3 & 0,3 & 0,4 \\
\hline Net profit/Net Sales (\%) & $-1,0$ & 2,2 & 5,1 & $-0,3$ & 4,2 & 4,4 & 5,6 & 4,8 & 5,3 & 5,9 & 5,2 & 4,7 & 4,0 & 2,9 & 6,0 & 5,2 & 4,7 & 2,1 & 3,3 & 5,0 \\
\hline Foreign & 1993 & 1994 & 1995 & 1996 & 1997 & 1998 & 1999 & 2000 & 2001 & 2002 & 2003 & 2004 & 2005 & 2006 & 2007 & 2008 & 2009 & 2010 & 2011 & 2012 \\
\hline \multicolumn{21}{|l|}{ AGRICULTURE } \\
\hline ROA (\%) & 2,0 & 3,2 & 2,8 & 4,4 & 2,6 & 22,3 & 5,9 & 7,9 & 3,3 & 3,1 & 7,9 & 2,1 & 5,1 & 4,6 & 0,4 & 8,1 & 5,6 & 2,6 & 2,0 & 4,5 \\
\hline Net Sales/Total Assets & 0,9 & 1,0 & 0,9 & 1,1 & 0,7 & 0,7 & 0,6 & 0,7 & 0,4 & 0,5 & 1,0 & 0,8 & 1,0 & 1,0 & 1,4 & 1,3 & 1,3 & 1,3 & 1,0 & 0,9 \\
\hline Net profit/Net Sales (\%) & 2,1 & 3,4 & 3,1 & 3,9 & 3,5 & 30,0 & 9,9 & 12,0 & 7,7 & 6,2 & 8,1 & 2,7 & 5,2 & 4,6 & 0,3 & 6,2 & 4,2 & 1,9 & 1,9 & 4,9 \\
\hline \multicolumn{21}{|l|}{ INDUSTRY } \\
\hline ROA (\%) & $-0,1$ & 2,2 & 4,8 & 7,7 & 12,4 & 11,7 & 9,6 & 8,7 & 6,2 & 7,5 & 8,4 & 8,1 & 7,3 & 7,8 & 10,6 & 3,5 & 3,2 & 5,2 & 3,2 & 4,3 \\
\hline Net Sales/Total Assets & 0,9 & 1,0 & 1,2 & 1,2 & 1,3 & 1,4 & 1,4 & 1,4 & 1,4 & 1,4 & 1,3 & 1,3 & 1,4 & 1,5 & 1,5 & 1,6 & 1,3 & 1,2 & 1,2 & 1,4 \\
\hline Net profit/Net Sales (\%) & $-0,2$ & 2,2 & 4,1 & 6,5 & 9,4 & 8,5 & 6,9 & 6,5 & 4,4 & 5,2 & 6,3 & 6,3 & 5,4 & 5,2 & 7,3 & 2,2 & 2,4 & 4,4 & 2,7 & 3,0 \\
\hline \multicolumn{21}{|c|}{ CONSTRUCTION INDUSTRY } \\
\hline ROA (\%) & 1,5 & 3,5 & $-3,4$ & $-0,2$ & 1,7 & 4,6 & 3,4 & 2,0 & 3,2 & 2,3 & 1,2 & 6,5 & 2,9 & 3,7 & 3,9 & 1,6 & $-0,6$ & $-4,4$ & $-1,8$ & $-0,6$ \\
\hline Net Sales/Total Assets & 1,5 & 1,8 & 1,7 & 1,5 & 1,0 & 1,2 & 1,1 & 0,9 & 1,1 & 0,9 & 0,9 & 1,9 & 0,9 & 1,0 & 1,0 & 1,2 & 1,5 & 1,2 & 0,9 & 1,0 \\
\hline Net profit/Net Sales (\%) & 1,0 & 2,0 & $-2,0$ & $-0,1$ & 1,8 & 4,0 & 3,1 & 2,3 & 2,9 & 2,6 & 1,3 & 3,4 & 3,1 & 3,8 & 3,9 & 1,3 & $-0,4$ & $-3,6$ & $-1,9$ & $-0,6$ \\
\hline \multicolumn{21}{|c|}{ TRADE } \\
\hline ROA (\%) & $-1,8$ & $-1,5$ & $-2,4$ & $-0,1$ & 2,7 & 4,6 & 4,5 & 4,1 & 5,6 & 6,3 & 6,6 & 7,1 & 6,1 & 3,6 & 6,0 & $-3,2$ & 1,0 & $-1,1$ & $-1,4$ & $-0,3$ \\
\hline Net Sales/Total Assets & 2,1 & 2,2 & 2,2 & 2,3 & 2,2 & 2,6 & 2,5 & 2,3 & 2,3 & 2,4 & 2,3 & 1,9 & 2,0 & 2,1 & 2,0 & 2,1 & 1,9 & 2,0 & 2,0 & 2,2 \\
\hline \multicolumn{21}{|c|}{ SERVICE } \\
\hline ROA (\%) & $-2,0$ & $-3,7$ & $-2,8$ & 1,9 & 1,6 & 2,3 & 2,4 & 2,6 & 3,5 & 1,9 & 2,7 & 3,1 & 3,6 & 3,5 & 2,9 & 2,5 & 1,2 & 0,7 & 0,1 & 0,4 \\
\hline Net Sales/Tc & 1,0 & 0,6 & 0,5 & 0,3 & 0,3 & 0,3 & 0,3 & 0,3 & 0,3 & 0,2 & 0,2 & 0,2 & 0,2 & 0,2 & 0,2 & 0,2 & 0,2 & 0,2 & 0,2 & 0,2 \\
\hline Net profit/Net Sales (\%) & $-2,0$ & $-5,9$ & $-5,5$ & 6,3 & 6,0 & 6,8 & 8,4 & 9,2 & 12,7 & 8,9 & 13,0 & 14,8 & 18,1 & 18,1 & 15,9 & 12,6 & 6,3 & 3,7 & 0,3 & 2,2 \\
\hline
\end{tabular}


Table 7. The DUPONT Model (ROE)

\begin{tabular}{|c|c|c|c|c|c|c|c|c|c|c|c|c|c|c|c|c|c|c|c|c|}
\hline Domestic & 1993. & 1994. & 1995. & 1996. & 1997. & 1998. & 1999. & 2000. & 2001. & 2002. & 2003. & 2004. & 2005. & 2006. & 2007. & 2008. & 2009. & 2010. & 2011. & 2012. \\
\hline \multicolumn{21}{|l|}{ AGRICULTURE } \\
\hline ROE (\%) & $-2,6$ & 4,3 & 7,3 & 7,2 & 5,9 & 6,2 & 1,7 & 2,6 & 6,9 & 5,8 & $-2,4$ & 2,8 & 4,9 & 5,2 & 4,6 & 5,6 & 4,5 & 3,1 & 8,1 & 7,6 \\
\hline ROA (\%) & $-1,9$ & 3,2 & 5,2 & 4,9 & 3,7 & 3,8 & 1,0 & 1,5 & 4,0 & 3,4 & $-1,3$ & 1,5 & 2,4 & 2,8 & 2,5 & 3,0 & 2,5 & 1,8 & 4,8 & 4,5 \\
\hline Total Assets/Equity & 1,3 & 1,4 & 1,4 & 1,5 & 1,6 & 1,6 & 1,7 & 1,8 & 1,7 & 1,7 & 1,8 & 1,9 & 2,0 & 1,9 & 1,9 & 1,9 & 1,8 & 1,7 & 1,7 & 1,7 \\
\hline \multicolumn{21}{|l|}{ INDUSTRY } \\
\hline ROE (\%) & $-0,9$ & $-0,4$ & $-0,6$ & 1,1 & 4,4 & 4,0 & 6,3 & 6,9 & 6,6 & 4,1 & 6,1 & 11,4 & 14,8 & 14,7 & 13,6 & 9,3 & 9,4 & 9,3 & 15,3 & 8,5 \\
\hline ROA (\%) & $-0,7$ & $-0,3$ & $-0,5$ & 0,8 & 2,8 & 2,3 & 3,6 & 3,8 & 3,7 & 2,2 & 3,1 & 6,0 & 7,9 & 7,7 & 6,3 & 3,9 & 4,5 & 4,7 & 6,6 & 4,6 \\
\hline Total Assets/Equity & 1,4 & 1,4 & 1,4 & 1,4 & 1,6 & 1,8 & 1,7 & 1,8 & 1,8 & 1,9 & 2,0 & 1,9 & 1,9 & 1,9 & 2,2 & 2,4 & 2,1 & 2,0 & 2,3 & 1,9 \\
\hline \multicolumn{21}{|c|}{ CONSTRUCTION INDUSTRY } \\
\hline ROE (\%) & $-2,7$ & 5,8 & 13,3 & 15,6 & 23,0 & 16,4 & 35,2 & 23,1 & 21,2 & 17,9 & 20,5 & 18,4 & 20,6 & 14,0 & 12,8 & 16,6 & 12,0 & 5,6 & 11,1 & 14,0 \\
\hline ROA (\%) & $-1,0$ & 2,1 & 4,5 & 5,1 & 7,9 & 6,4 & 11,3 & 7,1 & 6,5 & 6,5 & 6,6 & 5,5 & 5,3 & 3,6 & 3,8 & 4,6 & 3,6 & 1,7 & 3,3 & 4,9 \\
\hline Total Assets/Equity & 2,7 & 2,8 & 3,0 & 3,0 & 2,9 & 2,6 & 3,1 & 3,2 & 3,3 & 2,8 & 3,1 & 3,3 & 3,9 & 3,9 & 3,4 & 3,6 & 3,3 & 3,3 & 3,4 & 2,8 \\
\hline \multicolumn{21}{|l|}{ TRADE } \\
\hline ROE (\%) & $-0,3$ & 2,4 & 6,8 & 8,4 & 12,3 & 13,8 & 13,0 & 14,3 & 17,5 & 20,9 & 22,2 & 20,3 & 12,7 & 18,6 & 18,6 & 10,6 & 10,5 & 19,5 & 11,6 & 7,4 \\
\hline ROA (\%) & $-0,1$ & 1,0 & 2,6 & 3,1 & 4,3 & 4,7 & 4,5 & 4,6 & 5,7 & 6,8 & 7,0 & 6,4 & 3,7 & 6,0 & 5,6 & 3,2 & 3,0 & 6,1 & 3,6 & 2,4 \\
\hline Total Assets/Equity & 2,3 & 2,4 & 2,6 & 2,7 & 2,9 & 3,0 & 2,9 & 3,1 & 3,1 & 3,1 & 3,2 & 3,2 & 3,4 & 3,1 & 3,3 & 3,3 & 3,6 & 3,2 & 3,2 & 3,1 \\
\hline \multicolumn{21}{|l|}{ SERVICE } \\
\hline ROE (\%) & $-0,5$ & 1,5 & 4,3 & $-0,2$ & 4,1 & 5,2 & 6,9 & 6,5 & 8,7 & 10,8 & 10,1 & 9,2 & 9,2 & 6,5 & 10,5 & 9,7 & 8,2 & 3,7 & 6,0 & 8,7 \\
\hline ROA (\%) & $-0,4$ & 1,0 & 2,8 & $-0,1$ & 1,4 & 1,8 & 2,4 & 2,2 & 2,4 & 3,7 & 3,0 & 2,2 & 1,9 & 1,6 & 2,7 & 1,8 & 1,5 & 0,7 & 1,1 & 1,8 \\
\hline Total Assets/Equity & 1,4 & 1,5 & 1,5 & 3,2 & 3,0 & 2,9 & 2,9 & 3,0 & 3,6 & 2,9 & 3,4 & 4,2 & 5,0 & 4,1 & 3,9 & 5,3 & 5,6 & 5,4 & 5,4 & 4,9 \\
\hline Foreign & 1993. & 1994. & 1995. & 1996. & 1997. & 1998. & 1999. & 2000. & 2001. & 2002. & 2003. & 2004. & 2005. & 2006. & 2007. & 2008. & 2009. & 2010. & 2011. & 2012. \\
\hline \multicolumn{21}{|l|}{ AGRICULTURE } \\
\hline ROE (\%) & 2,9 & 5,5 & 5,1 & 9,0 & 4,8 & 51,4 & 10,8 & 16,8 & 7,0 & 5,6 & 13,0 & 5,7 & 15,4 & 11,7 & 0,9 & 11,9 & 9,6 & 4,4 & 3,3 & 9,1 \\
\hline ROA (\%) & 2,0 & 3,2 & 2,8 & 4,4 & 2,6 & 22,2 & 5,9 & 7,9 & 3,3 & 3,1 & 7,9 & 2,1 & 5,1 & 4,6 & 0,4 & 8,1 & 5,6 & 2,6 & 2,0 & 4,5 \\
\hline Total Assets/Equity & 1,5 & 1,7 & 1,8 & 2,1 & 1,9 & 2,3 & 1,8 & 2,1 & 2,1 & 1,8 & 1,7 & 2,7 & 3,0 & 2,6 & 2,0 & 1,5 & 1,7 & 1,7 & 1,7 & 2,0 \\
\hline \multicolumn{21}{|l|}{ INDUSTRY } \\
\hline ROE (\%) & $-0,3$ & 4,4 & 9,5 & 13,4 & 23,1 & 21,7 & 18,4 & 17,4 & 12,9 & 14,1 & 14,8 & 14,3 & 14,8 & 14,9 & 19,5 & 6,7 & 6,1 & 11,4 & 6,3 & 9,5 \\
\hline ROA (\%) & $-0,1$ & 2,2 & 4,8 & 7,7 & 12,4 & 11,7 & 9,6 & 8,7 & 6,2 & 7,5 & 8,4 & 8,1 & 7,3 & 7,8 & 10,6 & 3,5 & 3,2 & 5,2 & 3,2 & 4,3 \\
\hline Total Assets/Equity & 1,9 & 2,0 & 2,0 & 1,7 & 1,9 & 1,9 & 1,9 & 2,0 & 2,1 & 1,9 & 1,8 & 1,8 & 2,0 & 1,9 & 1,9 & 1,9 & 1,9 & 2,2 & 2,0 & 2,2 \\
\hline \multicolumn{21}{|c|}{ CONSTRUCTION INDUSTRY } \\
\hline ROE (\%) & 3,4 & 8,4 & $-10,4$ & $-0,5$ & 7,6 & 17,1 & 12,2 & 6,8 & 8,9 & 8,4 & 4,7 & 26,3 & 17,0 & 21,7 & 23,1 & 9,1 & $-4,2$ & $-22,7$ & $-8,3$ & $-2,7$ \\
\hline ROA (\%) & 1,5 & 3,5 & $-3,4$ & $-0,2$ & 1,7 & 4,6 & 3,4 & 2,0 & 3,2 & 2,3 & 1,2 & 6,5 & 2,9 & 3,7 & 3,9 & 1,6 & $-0,6$ & $-4,4$ & $-1,8$ & $-0,6$ \\
\hline Total Assets/Equity & 2,3 & 2,4 & 3,1 & 2,8 & 4,4 & 3,7 & 3,6 & 3,4 & 2,8 & 3,6 & 3,8 & 4,1 & 6,0 & 5,9 & 6,0 & 5,9 & 6,6 & 5,2 & 4,6 & 4,6 \\
\hline \multicolumn{21}{|l|}{ TRADE } \\
\hline ROE (\%) & $-6,7$ & $-6,4$ & $-9,3$ & $-0,4$ & 9,8 & 15,8 & 15,8 & 14,8 & 15,9 & 17,4 & 19,6 & 19,9 & 19,3 & 8,6 & 14,3 & $-10,0$ & 2,5 & $-2,9$ & $-4,0$ & $-0,7$ \\
\hline ROA (\%) & $-1,8$ & $-1,5$ & $-2,4$ & $-0,1$ & 2,7 & 4,6 & 4,5 & 4,1 & 5,6 & 6,3 & 6,6 & 7,1 & 6,1 & 3,6 & 6,0 & $-3,2$ & 1,0 & $-1,1$ & $-1,4$ & $-0,3$ \\
\hline Total Assets/Equity & 3,7 & 4,3 & 3,9 & 3,0 & 3,6 & 3,4 & 3,5 & 3,6 & 2,8 & 2,8 & 3,0 & 2,8 & 3,2 & 2,4 & 2,4 & 3,1 & 2,5 & 2,7 & 3,0 & 2,8 \\
\hline \multicolumn{21}{|l|}{ SERVICE } \\
\hline ROE (\%) & $-4,1$ & $-12,2$ & $-6,5$ & 7,6 & 8,9 & 11,6 & 14,1 & 8,1 & 9,6 & 8,7 & 13,4 & 15,3 & 20,4 & 23,0 & 19,1 & 17,6 & 7,3 & 4,6 & 0,3 & 1,9 \\
\hline ROA (\%) & $-2,0$ & $-3,7$ & $-2,8$ & 1,9 & 1,6 & 2,3 & 2,4 & 2,6 & 3,5 & 1,9 & 2,7 & 3,1 & 3,6 & 3,5 & 2,9 & 2,5 & 1,2 & 0,7 & 0,1 & 0,4 \\
\hline Total Assets/Equity & 2,5 & 3,3 & 2,3 & 4,1 & 5,6 & 5,1 & 5,9 & 3,2 & 2,7 & 4,5 & 5,1 & 4,9 & 5,7 & 6,5 & 6,6 & 7,1 & 6,1 & 6,6 & 6,8 & 4,5 \\
\hline
\end{tabular}

\section{Conclusions and Proposals}

We recommend financial planning to the operational sales revenues on the basis of the internal and sustainable growth rates calculation. It can be derived from - the basis for the following year financial parameters of the our enterprise the operating expenses and EBIT, income and expense portion of the investment and funding proposals, the marginal tax rate assumed after-tax profits, and from that payable dividends and retained profit (Katits-Szalka, 2014). 
In summary, the biggest companies belonging national economic sector's owners not have felt in a favorable position themselves because the ROE, ROA value and the Assets/Equity ratio.

Those national economic sectors that are relatively high operating and net profit growth has been achieved, not achieved a significant return on shareholder equity (ROE) basis. Although profitable growth enjoys the highest priority of our study also shows that failed to achieve sustained profitable growth.

During the financial analysis of the national economic sector the net sales growth rates were relatively favorable, but the profitability, the negative trend in asset efficiency showed many weaknesses.

Among the activities and strategies of growth stimulating decisions distinction could be made in the short and long term. The short-term growth strategy of the business portfolio structuring (basic, growing and future groups of classes), to the products, especially in the market and financial assessment. The long-term growth strategy is based on the key success factors of long-term growth. Here you can play the role of assets rights (patents, know-how, inventions, intellectual knowledge and experience), brand loyalty, etc. development.

Today, innovation is the key to long term success. The innovation of the survival and growth engine, which presupposes a large investment in time and time again. The investment is the breeding ground for internal corporate growth, which makes it possible companies to be innovative. I do not happen to Rappaport's [11, 12] one of the corporate value of the the additional driver required the additional fixed asset turnover and working capital, which was low - in fact, not only showed a positive change - for the national economic sectors we examined. This has slowed the innovation must be changed!

\section{Appendices}

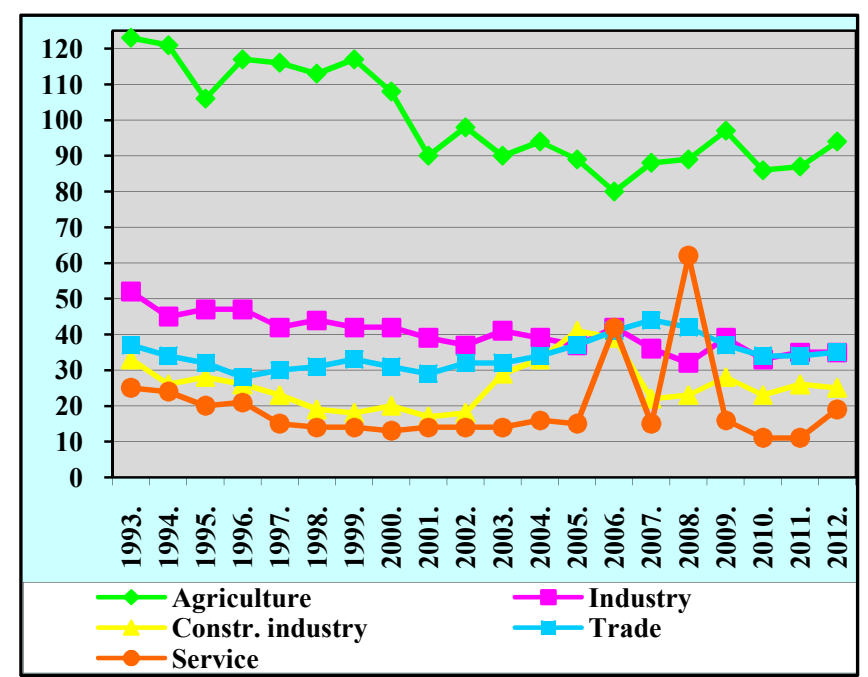

Appendix 1a. The Hungarian TOP 5000 - LIFE OF INVENTORY (DOMESTIC majority ownership, in days)

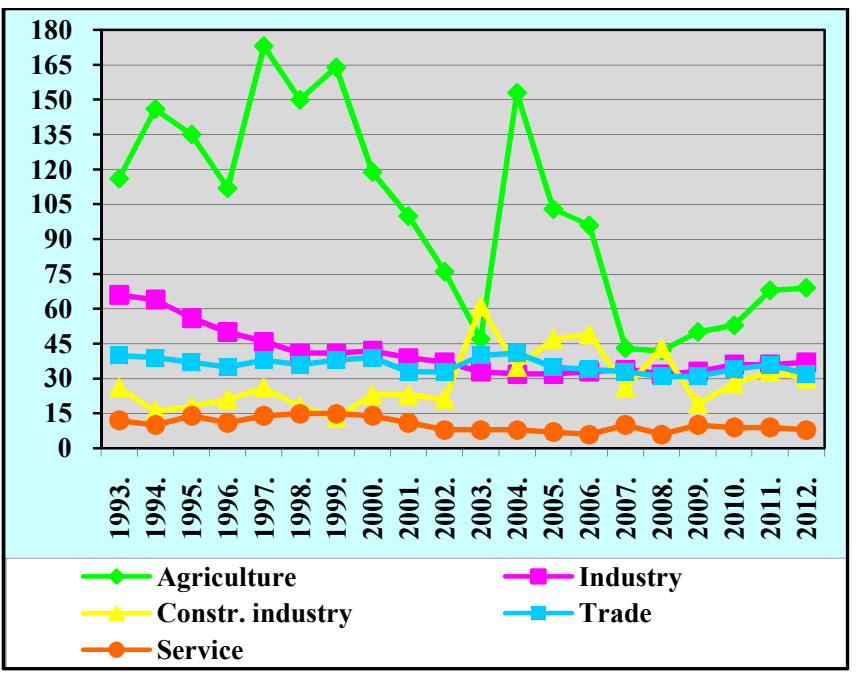

Appendix 1b. The Hungarian TOP 5000 - LIFE OF INVENTORY (FOREIGN majority ownership, in days)

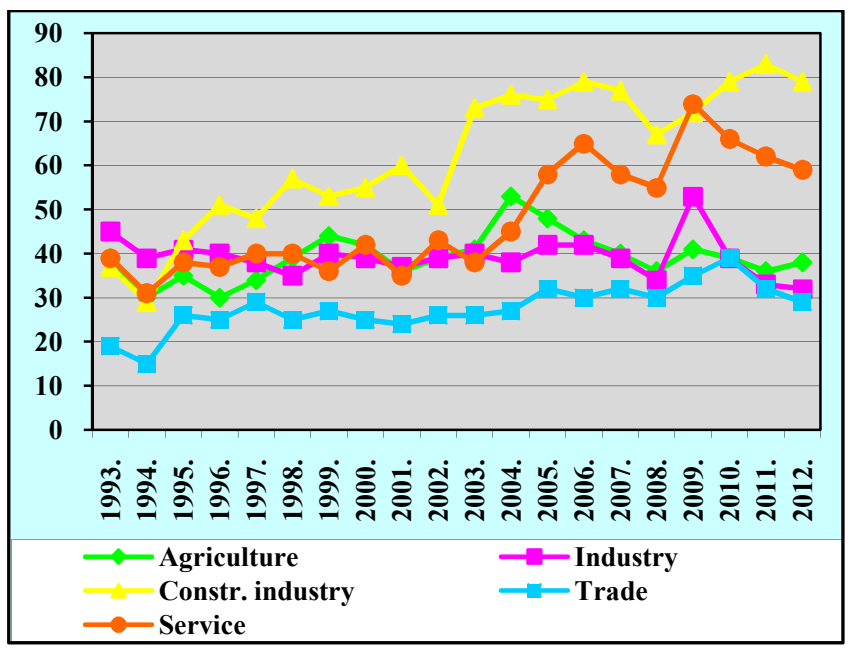

Appendix 2a. The Hungarian TOP 5000 - ACCOUNTS RECEIVABLE WAITING PERIOD (DOMESTIC majority ownership, in days)

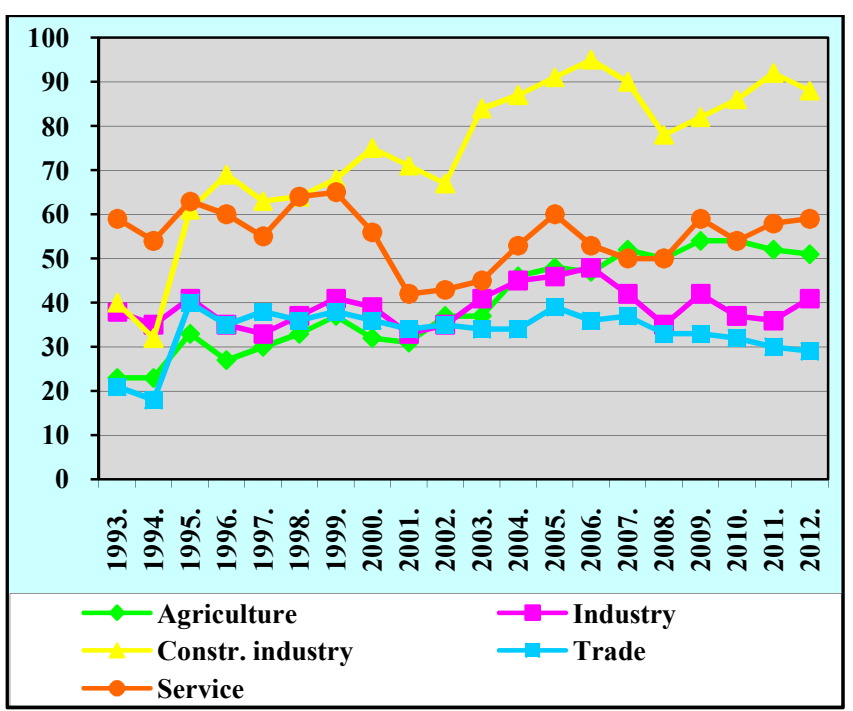

Appendix 2b. The Hungarian TOP 5000 - PAYMENT PERIOD OF THE ACCOUNTS PAYABLE (DOMESTIC majority ownership, in days) 


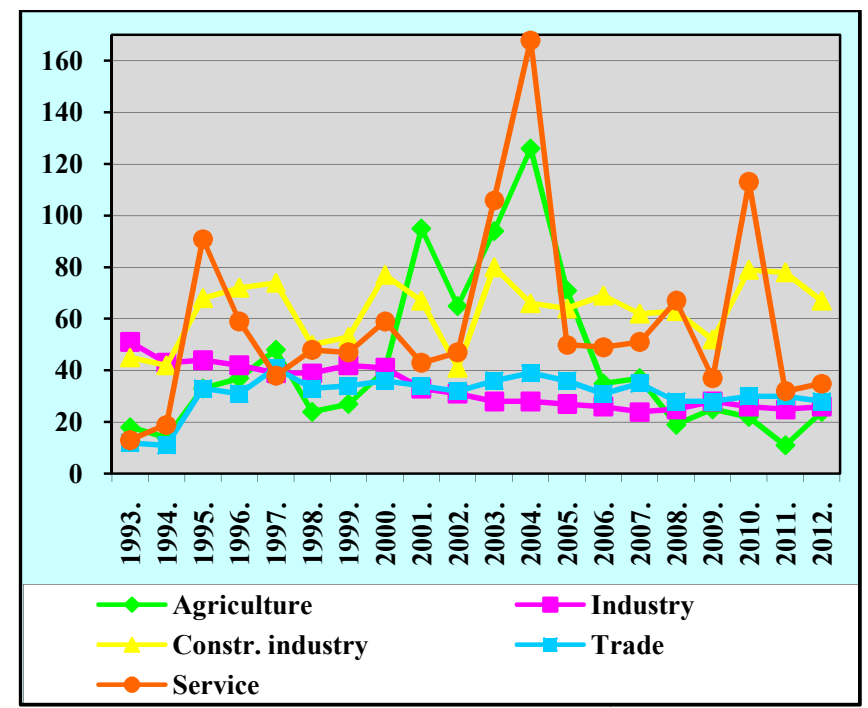

Appendix 3a. The Hungarian TOP 5000 - ACCOUNTS RECEIVABLE WAITING PERIOD (FOREIGN majority ownership, in days)

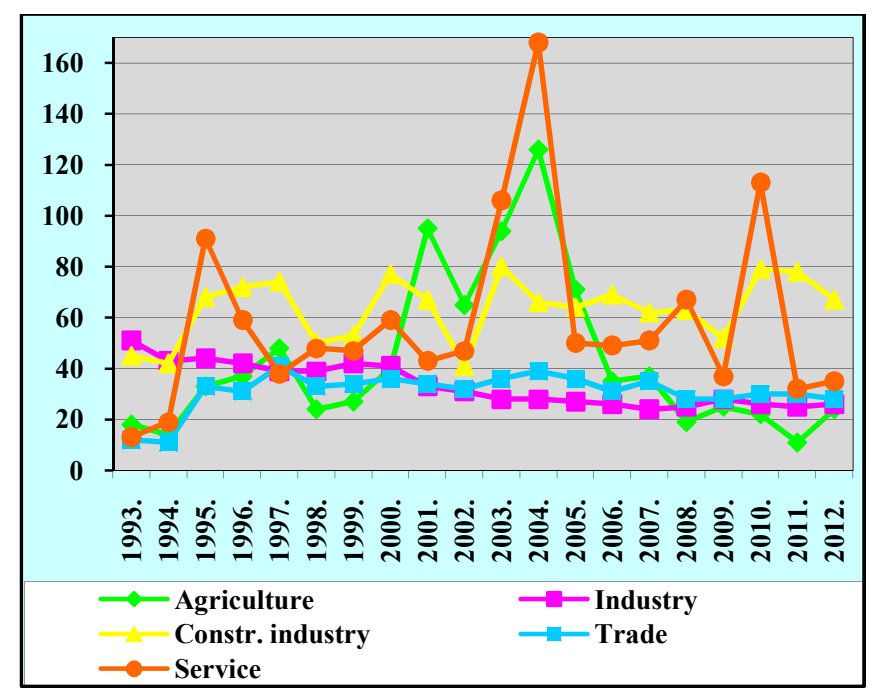

Appendix 3b. The Hungarian TOP 5000 - PAYMENT PERIOD OF THE ACCOUNTS PAYABLE (FOREIGN majority ownership, in days)

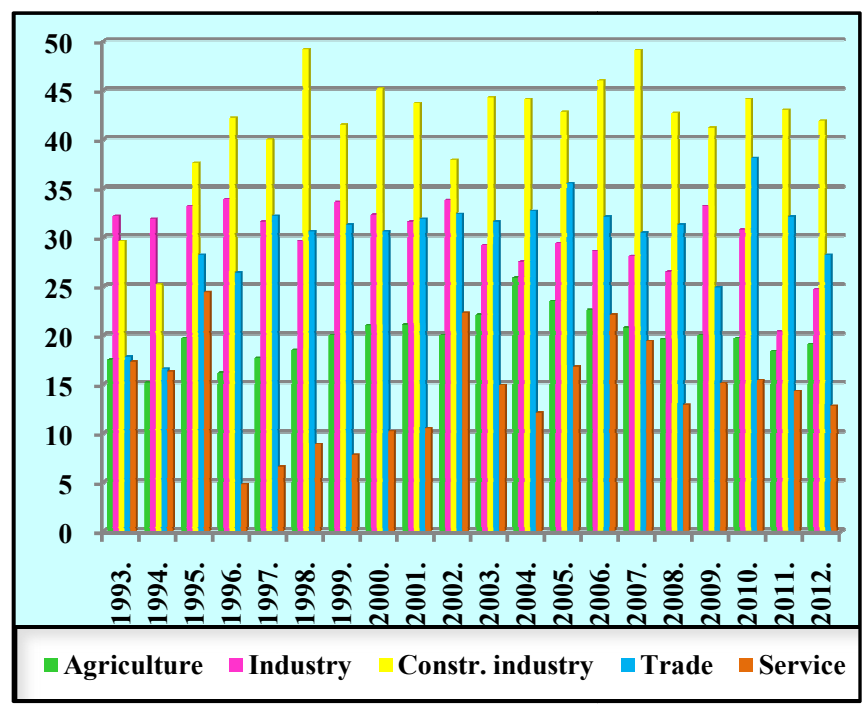

Appendix 4a. The Hungarian TOP 5000 - ACCOUNTS RECEIVABLE/ CURRENT ASSETS rates (DOMESTIC majority ownership, in percent)

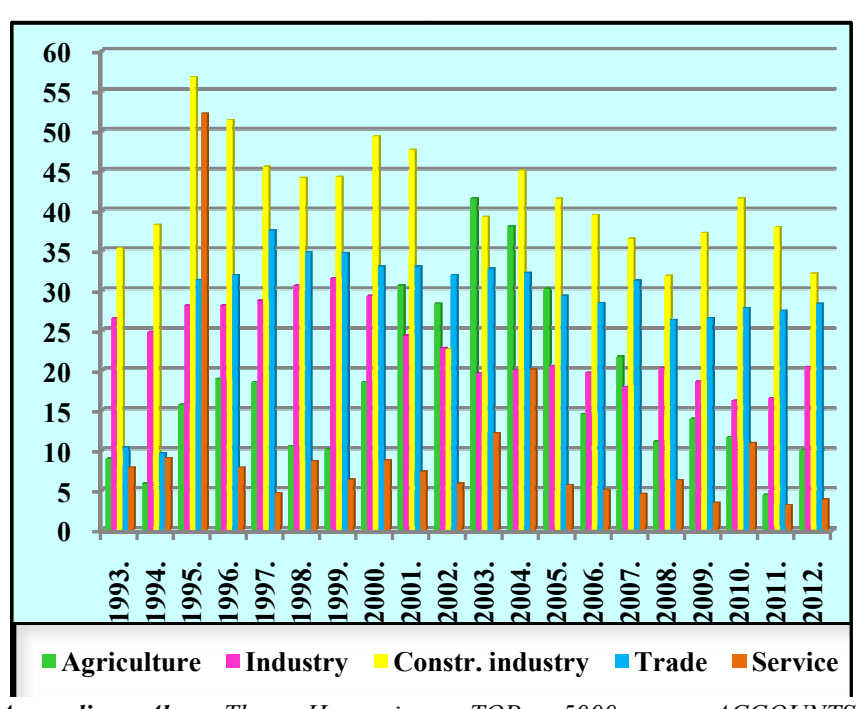

Appendix 4b. The Hungarian TOP 5000 - ACCOUNTS RECEIVABLE/CURRENT ASSETS rates (FOREIGN majority ownership, in percent)

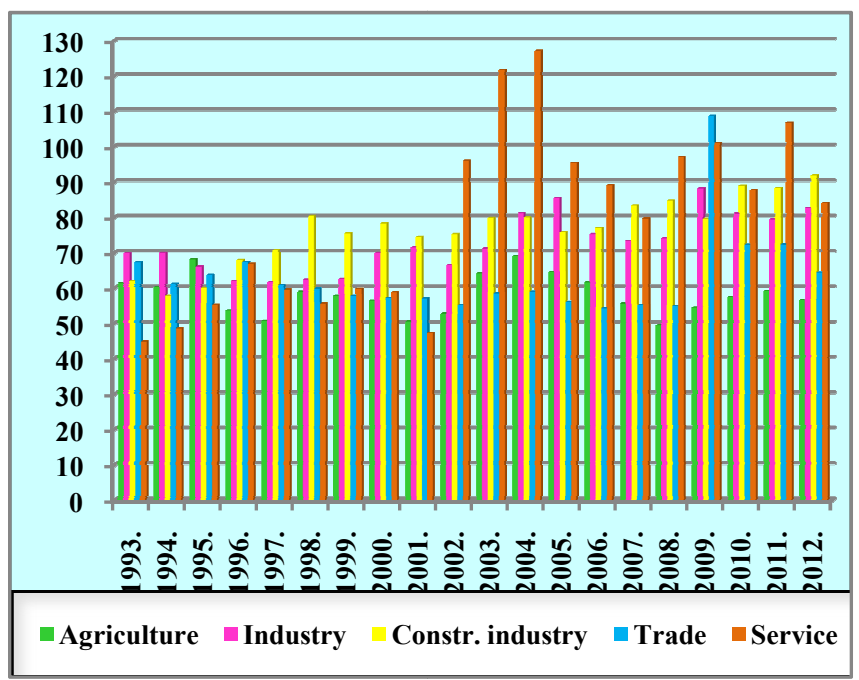

Appendix 5a. The Hungarian TOP 5000 - CLAIMS/SHORT TERM LIABILITIES rates (DOMESTIC majority ownership, in percent)

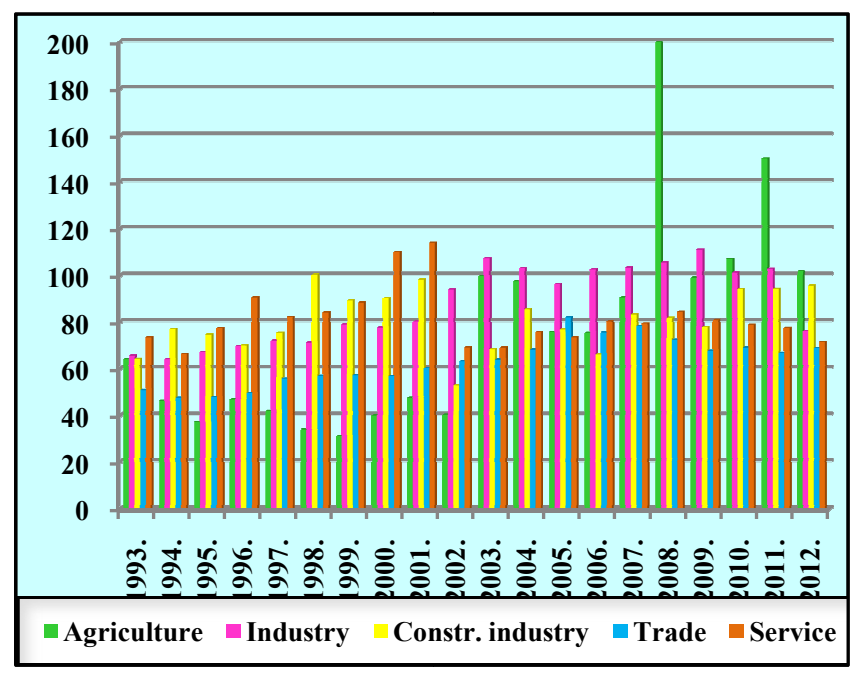

Appendix 5b. The Hungarian TOP 5000 - CLAIMS/SHORT TERM LIABILITIES rates (FOREIGN majority ownership, in percent) 


\section{References}

[1] G. C. Babcock, „The Concept of Sustainable Growth”, Financial Analysts Journal, 1970, pp. 108-114.

[2] P. Chandra, "Financial Management", Tata McGraw-Hill, 2011, pp. 123-124.

[3] N. C. Churchill and J. W. Mullins, "How Fast Can Your Company Afford to Growth?", Harvard Business Review, 2001, pp. 135-143.

[4] R. C. Higgins, "Sustainable Growth under Inflation", Financial Management, 1981, pp. 36-40.

[5] E. Katits, "The Fundamentals of Corporate Management", Saldo, Budapest, p. 258.

[6] E. Katits, L. Z. Kucséber and É. Szalka, "The Corporate Life Cycles and Organizational Restructurings Examination, or the External versus Internal Growth", International Scientific Conference on the Occasion of Hungarian Science Festival, University of West Hungary, Faculty of Economics, Sopron, 2013. 11. 12.

[7] E. Katits, J. Koltai and É. Szalka, "The Hungarian's Top 100 and the Financial Crisis, or to Strengthen the Internal Financing Force", 'Growth and Balance' Kautz Gyula Memoraial Conference, Széchenyi István University, Kautz Gyula Faculty of Economics, ör, 2013. 06. 17. http://kgk.sze.hu/images/dokumentumok/kautzkiadvany2013/ valtozas/szalka koltai katits.pdf p. 11 .

[8] C. F. Lee and A. C. Lee, "Encyclopdia of Finance", Springer Science \& Business Media, 2006, p. 152.

[9] K. H. Marks, L. E. Robbins, G. Fernandez, J. P. Funkhoser and D. L. Williams, "The Handbook of Financing Growth: Strategies, Capital Structure, and M\&A Transactions", John Wiley \& Sons, Inc., Hoboken, New Jersey, 2009, pp. 568-645.

[10] R. Parrino, P. Moles and D. S. Kidwell, "Fundamentals of Corporate Finance", Hoboken, John Wiley\&Sons, 2011, 760 p.

[11] A. Rappaport, "Shareholder Value. The New Standard for Business Performance", New York, Free Press, 1986, pp. 5069.

[12] A. Rappaport, "Creating Shareholder Value: A Guide for Managers and Investors", Simon and Schuster, New York, 1999 , pp. 55-57.

[13] J. C. Van Horne and J. M. Waczhowicz, "Fundamentals of Financial Management", Pearson Education, 2008, pp. 190198.

[14] Verlag Dashöfer, software, "Comprehensive Reporting and Evaluation", software, 1999. Budapest, 2000.

[15] S. R. Vishwanath, "Corporate Finance: Theory and Practice", SAGE Publications India, 2007, pp. 275-277.

[16] B. Zane, A. Kane and A. J. Marcus, Essentials of Investments, McGraw-Hill Irwin, 2004, pp.458-460.

[17] S. R. Vishwanath, "Corporate Finance: Theory and Practice", SAGE Publications India, 2007, pp. 275-277.

[18] B. Zane, A. Kane and A. J. Marcus, Essentials of Investments, McGraw-Hill Irwin, 2004, pp.458-460. 